超短波間脳照射の骨髄造血機能に及ほすす影響

\author{
第 一 編 \\ 超短波間膇照射による骨葡の血球動員並に坜留に就て
}

岡山大学医学部平木内科数室（主任：平木 㵖数授）

撛師藤森明良

[昭和 32 年 9 月 6 日受稿]

\section{第1章 緒言 \\ 第 2 章 実験材料並に実験方法 \\ 第 3 章 実臨成績 \\ 第 1 節 3 分間 1 回照射の場合 \\ 第 2 節 3 分間連統照射の場合 \\ 第 3 節 30 分間照射の”場合}

内容目次

\section{第1章 緒言}

高周波電気療法は $\boldsymbol{\alpha}^{\prime}$ Arsonvalisation の原 始的療法に始り, Diathermie 療法を経て短 波療法; 超短波療法, 極超短波療法へと進步 して来たが，現在超短波療法が最す広く利用 されている。双，超短波の生物学的作用飞就 ては，古来諸家により究明され，誘電体損失 Kよる温熱発生並にその特殊分布作用，特殊 電気的作用，化学的作用等が述べられてた り，自律神経系統並飞血液系統飞就ては, Cignoli1), Gandellini'2), Ostertag ${ }^{3)}$, Pflomm $^{4}$,

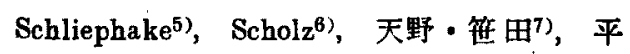

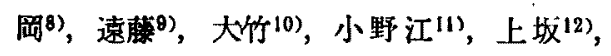
小宮 ${ }^{13}$ ，高橋(源) ${ }^{(4)}$, 高橋(源) - 造藤 ${ }^{15}$, 高

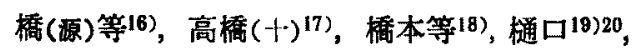
山本21)等の業繢がある.

扱, 血球の数量は生理的状態では略々一定

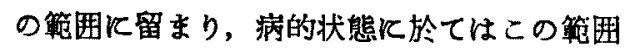
を越えて増減する。この様な血球の変動は, 何等かの調節機構のるとに営まれているであ ろうことは, 容易飞想像される所であり, 古 来諸家により研究されて来た所以でるある.
第 4 節 鈎虫症血清灌流後の 3 分間照射 の場合

第 5 節 骨髄体外組織培羡への影望

\section{第 4 章 実験成績の総括}

第 5 章 考按

第6 章 結 諭

自律中枢と血液像の関係飞就ての報告を見る

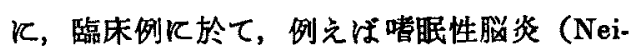

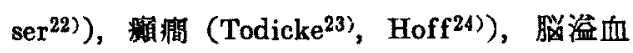

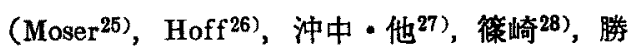
沼 $^{29)}$, 古川(30), 传藤 ${ }^{31)}$ ), 脳腫煬 (Moser ${ }^{26)}$ ), Parkinsonismus (Moser ${ }^{25)}$, Hoff ${ }^{26)}$ ) 等, 又, 外科的侵集, 即ち Pneumoencephalo-Ventriculographie 施行時 (Lichtwitz ${ }^{32}$ ), Hoff ${ }^{26)}$, Ginzberger u. Heilemyer ${ }^{33)}$, Castex ${ }^{34)}$, 山

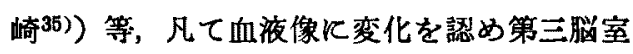
側壁部を重視している様である. 次飞 Wossi$\mathrm{dlo}^{36)}$, Denecke $\mathrm{e}^{37}$, 上坂 ${ }^{12}$, 橋本 - 高橋 $(\text { 源 })^{38}$, 古川・船川(39), 毛利40), 千田・井上41), 井 上・藤野42)等は短波チアテルミー，超短波或 は極超短波を，杉浦43)，野村44)，中村(三)45)，

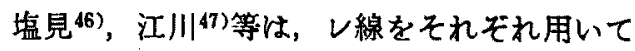
間脳照射を行い血液像の変化を検討してい る.

中枢神経を第制又心刺戟して血球調節中枢 の所在を追求したすのK Schulhof \& Matthies ${ }^{48)}$, Rosenow ${ }^{49) 60751)}$, Borchardt52)，亘・越 智53)54)65), 安藤 ${ }^{56)}$, 桜井 57), 串崎58), 林田59), 崎60)，油谷61)，杉浦43)等があり，その細部 
に就ては諸家により意見が異なるが，該中枢 が間脳に存在することは諸家の一致する所で あり，特に視床下部に存在するというのが支 配的である。

一方視床下部に自律神経の高位中枢が存在 する事は周知の事であるが，最近，西川・岡 本 ${ }^{63)}$ ，等は視㦿下部の中，第三脳室壁飞括け る黒津 ${ }^{64)}$ の所謂交感带並飞副交感带を刺戟 し，血液像の自律神経支配を追求している.

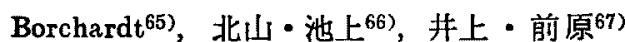
は温制载により血球增加が起ると述へてている が，前記亘・越智53)54)55） む灰白結節 穿刺の 際著明な血球増加と共飞，体温上昇，血糖増 加等が起ると述べている，かかる現象注血球 調節中枢々温熱中枢，糖中枢等の自律神経中 枢とが相近接する部位に存在し，穿刺に際し て共に過敏沉影響を受ける為と考兵られる。 従つてかかる実験に於ける間脳之末梢血液並 飞骨䯣造血機能との関係は，自律神経中枢飞 主幸される諸因子が加わることは避けがたい， 然しこれ等の諸因子を除外する意味で，交感 神経切除, 脊㕼後根の切除並飞刺戟等を行い， 骨髄に及ほす影響を観察したものに，浅井 ${ }^{68)}$, 森川 ${ }^{69)}$, 堀内 ${ }^{70)}$, 吉田 ${ }^{71)}$, 西川 = 凮本 ${ }^{62)}$, 教 室柴田 ${ }^{72)}$ 並飞永瀬・石田73) 等の研究があり， その結果は必ずしも一致しないが, Duverney $^{74)}$ ，竹山 ${ }^{75)}$ ，教室田中 ${ }^{76)}$ 等の骨鹃内神経 の研究と相俟つて，神経特飞自律神経が骨領 Kかなり大なる影䀌を与えていることは間違 いない.

ここに於て，私は超短波間脳照射を㮔々の 条件の々と行い，骨䯣栄静脈血像の推移

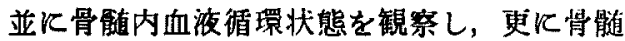
体外組織培䓔を行い，該照射の骨艏造血機能 に及ぼす影響を明らかにせんと企図し些か知 見を得たので茹に報告する。

\section{第 2 章 実殹材料並に実䀦方法}

1）実験動物：体重 $2 \mathrm{~kg}$ 内外の雄性白色 家鬼を用い10日間以上一定の生活状態飞捚致 せしめた後実䮖に供した。

2）超短波照射：波長 $6 \mathrm{~m}$ ，晹極电压 3000
Volt, 高周波出力 500 Watt, 入力 I KW の コマ医科工業株式会社製の超短波治療装置を 用い，二次回路の電流を，その一部に择入し た電流計により 2 anpere とし，電極は直径 $1 \mathrm{~cm}$ のンャーレー導子を用い, 并上(佬 $)^{77}$, 塩見 ${ }^{46}$ ) 飞做い電極の中心を外㫮外聴導結合線 の中点と一致せしめ 3 分間並に30分間照射を 行い，連続照射に於ては 24 時間間隔で行っ た.

3）骨髄栄養血管の露出：家鬼脊位固定後 井上 ${ }^{78}$ 亿做い，大腿中央部より鼠径靶带稍々 上方迄切開し，股動脈及び大腿骨栄養静脈を 笿出して実験を行つた。

4）血液諸検查：手術部を可及的清拭し， 大腿骨栄養静脈及び対照として股動脈より穿 刺飞よつて照射後時間招き飞約 8 時間乃至 24 時間迄採血し，赤血球数，網赤血球数，白血 球数並にその百分比を算定した，網赤血球は Pappenheim 氏法にて赤血球 1000 を数元千分 此を算定し，白血球百分比は Giemsa 染色江 より白血球 200 を数えて算出した。

5）骨䯣内血液循環状態の測定：教室創案 の平木・塩月79)の方法飞従いサイアシン骨䯣 灌流法を行つた，即ち家鬼大腿骨栄養血管を 露出して超短波照射を行い，1 万至 2 時間後 K1\%サイアシン (3, 4-Dimethyl-5-sulfanilamido-isoxazole) $0.1 \mathrm{cc}$ 栄養動脈中注射し， その後時間每に栄養静脈より $0.5 \mathrm{cc}$ 宛採血し 津田・松永 ${ }^{80)}$ の方法に従つて除蛋白した後デ アゾ化し，津田試㭼（ $\beta$-diethylaminoethyl-

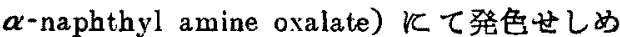
て，その血中サイアジン謷度を電気此色計 （日立製 TK-120 S) Kかけ，フィルターGを 用いて測定することにより曲線を得て骨䯣内 血流状態を推測した。

6）学髄組織標本の作製並飞観察：超短波 照射後 2 時間にして家鬼を空気栓塞で殺し， 大腿骨々䯣を採取し10\%の中性ホルマリンで 固定し，パラフィン包埋を行い切片の厚さを $5 \mu$ とし、へマトキンリンーエオンン重染色 を施し，対照として無処置健康家鬼の大腿骨 々艏を用い同様の標本を作製した，観察に当 
つては組織像を検すると共に，40視野（15× 100，千代田顕微鏡）中の骨䯣巨核球数索計算 した.

7）鈎虫症血清灌流実験：当科入院の合併 症なき鈎虫症患者の血清を無菌的飞分離し， 該血清を大腿骨栄養静脈飞 $0.4 \mathrm{cc}$ 注入乙，注 入後直に超短波 3 分間照射行つた。

8）骨娟体外組織培養：体重 $17 \mathrm{j}$ 至 $1.5 \mathrm{~kg}$ の健康家鬼の間脳を 3 分間並飞30分間各 1 回 照射，3 分間10日及び20日間連続照射を行い， 直後， 2 時間，24時間，48時間及び72時間後 に空気栓塞に上り殺し，可及的速かに大腿骨 々璡を無菌的に取出してリンダル氏没中にて 洗い，眼科用クレーフ，氏刀にて約 $1 \mathrm{~mm}^{3} の$ 稩片とし，これを培養材料とし教室大藤等 ${ }^{81)}$ 飞做つて被婹培羡を行つた。 即ち增生面積測 定には $37^{\circ} \mathrm{C}$ 飞保つた保温箱に顕篙鏡を入れ， アッン゚の描画器を用いて新生組織を描画し， 時間の経過を追つてその面積をプラニメータ を以て測定し実面皘に換算し，増生前後の差， 即ち絶対成長価の原面積に対する比率を比較 成長価とした，次に增生組織の機能的一面を 識る為に杉山氏日2)法を改良し体外組織培養飞 応用した教室亘理 ${ }^{83}$ の方法により，偽好酸球 の平均遊走速度を測定した，対照として無好 置家鬼に就て同様の実験を行つた。

\section{第3章実跧成縤}

第1節 3 分間 1 回照射の場合

第 1 項 血球数の変化

1）赤血球数

栄堢静脈血並に股動脈血の赤血球数は，第 1 表及び第 1 図に示す如く照射後 1 時間に最 高值に達し 3 時間後に旧に復したが，栄盖静 眽血に於ける増加の方が優位を示した，即ち No. 5 K於て栄養静脈血の赤血球数は, 照射 後 30 分より增加し始め，1 時間後に最高值 （16.8\%增）飞達し 3 時間後に旧復し，股 動脈血では1 時間後に最高值 (6.2 名増) に 達し 3 時間後飞旧飞復した。. No. 6 に於てる 同粎の変化を示し，栄美静脈並に股動脈血に 於て夫タ最高 $9.5 \% ， 6.5 \%$ の增加を示した。
第 1 表 3 分間 1 回照射せる場合の赤血 球系の変化

\begin{tabular}{|c|c|c|c|c|c|c|c|c|}
\hline \multirow{3}{*}{$\begin{array}{l}\text { 家 } \\
\text { 兔 } \\
\text { 番 } \\
\text { 号 }\end{array}$} & \multirow{3}{*}{$\begin{array}{l}\text { 検 } \\
\text { 查 } \\
\text { 時 } \\
\text { 間 }\end{array}$} & \multirow{3}{*}{$\mid \begin{array}{c}\text { 体 } \\
\text { 温 } \\
\left({ }^{\circ} \mathrm{C}\right)\end{array}$} & \multicolumn{2}{|c|}{ 赤血 球数 } & \multicolumn{4}{|c|}{ 網赤血球 数 } \\
\hline & & & \multirow{2}{*}{ 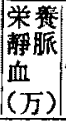 } & \multirow{2}{*}{ 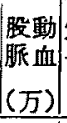 } & \multicolumn{2}{|c|}{ 栄羡靜脈血 } & \multicolumn{2}{|c|}{ 股趿脈血 } \\
\hline & & & & & $\%$ & 絶対数 & Tos & \\
\hline \multirow{7}{*}{$\begin{array}{r}\text { No. } \\
5\end{array}$} & 照射亩 & 38.9 & 528 & 546 & 14 & 73920 & 14 & 7644 \\
\hline & 分 & 39.0 & 552 & 547 & 20 & 110400 & 17 & 92990 \\
\hline & 1 㭙間 & 39.0 & 617 & 580 & 19 & 117230 & 23 & 133400 \\
\hline & $2 \%$ & & 572 & 576 & 23 & 131560 & 18 & 103680 \\
\hline & $"$ & & 502 & 535 & 19 & 95380 & 15 & 80250 \\
\hline & $"$ & 38.6 & 529 & 536 & 16 & 84640 & 16 & 85760 \\
\hline & $n$ & & 500 & 524 & 13 & & 9 & 47160 \\
\hline \multirow{7}{*}{$\begin{array}{c}\text { No. } \\
6\end{array}$} & 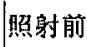 & 9.4 & 786 & 750 & 17 & & 18 & \\
\hline & 30 & 9.6 & 840 & 780 & 33 & 277200 & 20 & 156000 \\
\hline & 1 時間 & 39.0 & 861 & 799 & 35 & 301350 & 29 & 231710 \\
\hline & $2 "$ & & 835 & 778 & 15 & 125250 & 14 & 108920 \\
\hline & " & & 770 & 737 & 20 & 154000 & 10 & 73700 \\
\hline & $"$ & 39.5 & 760 & 756 & 11 & 83600 & 12 & 90720 \\
\hline & $" 1$ & & 740 & 731 & 11 & 81400 & 15 & 10965 \\
\hline
\end{tabular}

第 1 図 3 分間 1 回照射せる場合の 赤血球系の変化

上段 赤血球数 下段 網赤血球数
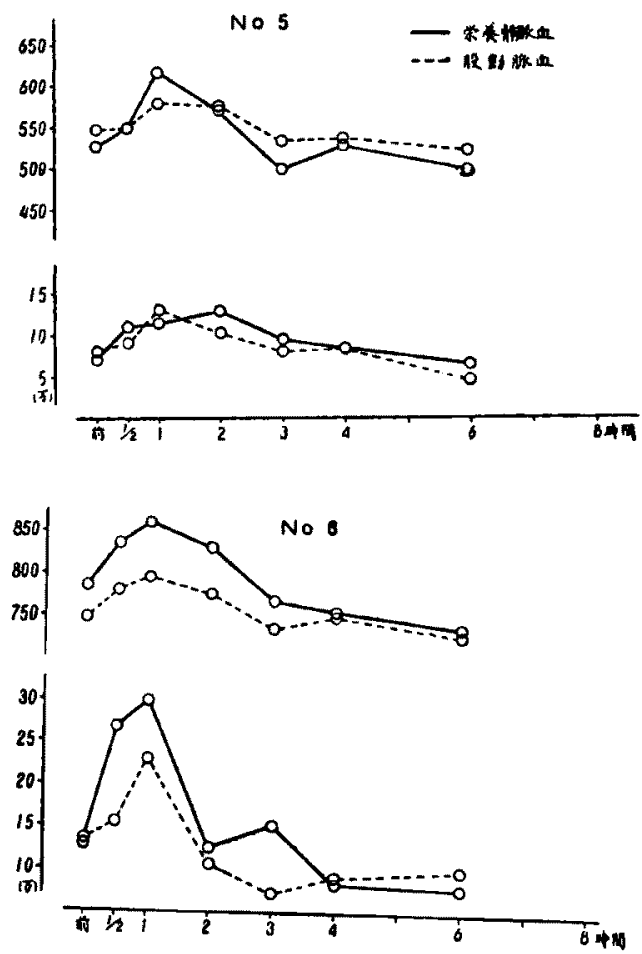
2）網赤血球数

栄養静脈血並に股動脈血の網赤血球数は， 第 1 表及び第 1 図に示す如く，その千分比並 飞絶対数は照射後 1 乃至 2 時間後に最高值に 達し 2 万至 4 時間後飞旧飞復したが，栄羡静 脈血に於ける増加は股動脈血のそれに比べて 早期に生じ增加の程度る大である. 即ち No. 5 の栄養静脈血並に股動脈血飞於ける最高值は $77.9 \% ， 74.5 \%$ 各增，No.6r於ては $125.5 \%$, 71.6\%各增であつた。

\section{3) 白血球数}

第 2 表，第 2 因の如く照射後30分より夈羡 静脈血の白血球数は, 股動脈血の白血球数に 先んじて増加し，その後共に増加し 6 乃至24 時間後に旧飞復した。 即ち No. 7 の栄養静脈 血では 30 分後に最高値 (109.6 \%增), 股動 脈血では 3 時間後飞最高值 (78.1\%增)，No. 8 の栄養静脈血では 30 分後飞最高值（77.3\% 增)，股動脈血では 2 洔間後飞最高檤 (130.7 \%增）飞達した。偽好酸球はその百分比で照

第 2 表 3 分間 1 回照射せる場合の白血球系の変化

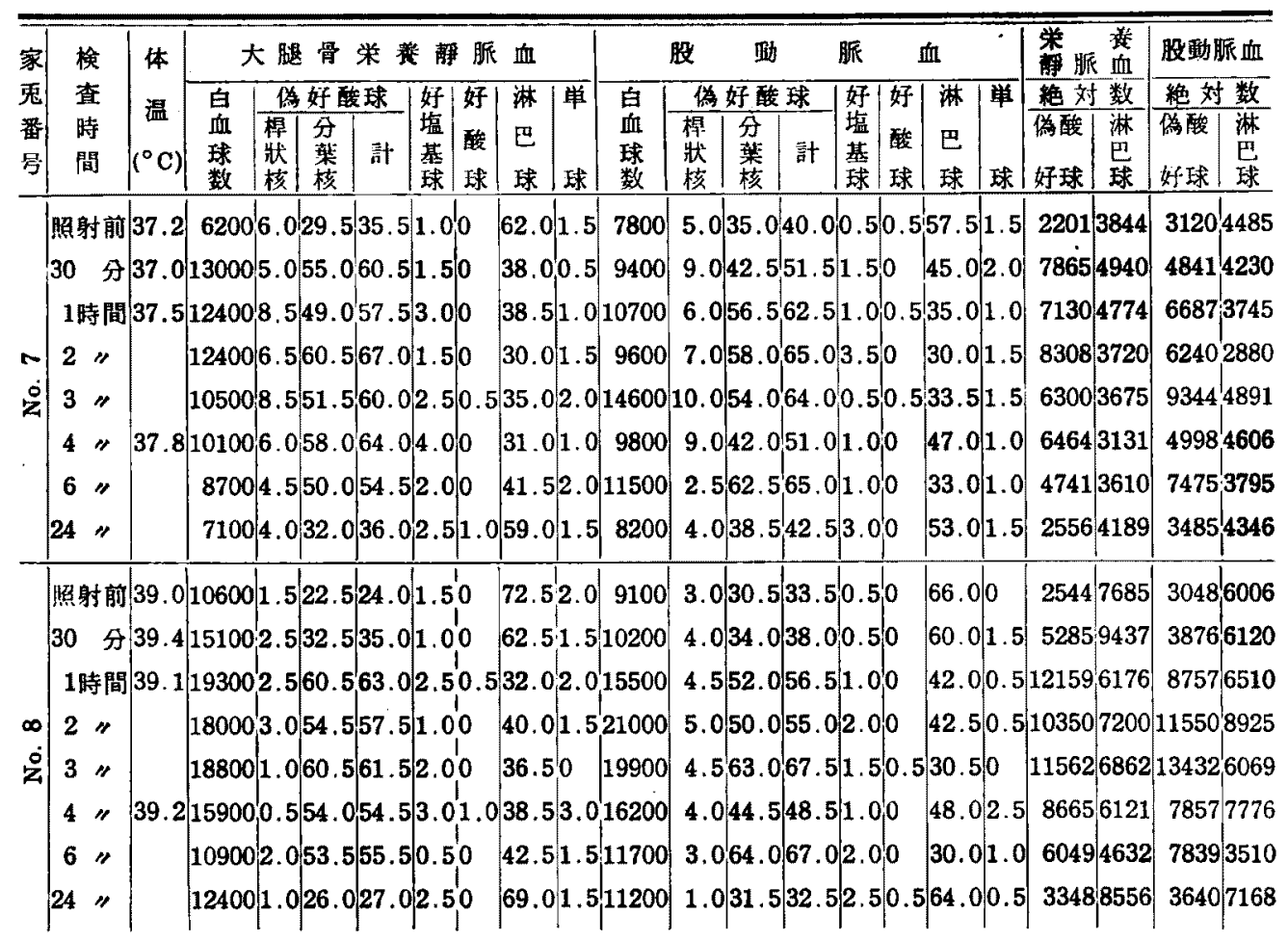

第 2 园 3 分間 1 回照射世る場合の白血球系の変化
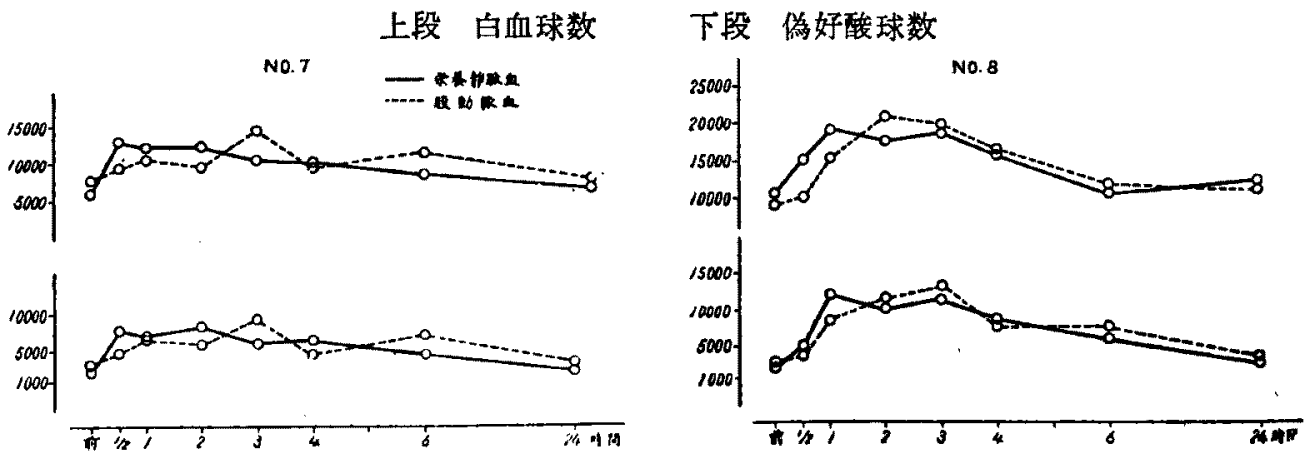
射後30分より軽度な核左方推移を伴う高度の 增多が見られ，その絶対数の增加は略々白血 球数の増加に一致して招り，No.7 の栄羡静 脈血で 2 時間後飞最高值 $(277.4 \%$ 增)，股 動脈血では 3 時間後飞最高值 (199.5\%增), No. 8 の栄養静脈血では 1 㭙間後に最高値 (377.9\%增)，股動脈血では 3 肪間佟に最高 值（340.6\%增）飞達し，共に白血球增加の 主因をなしている。
第 2 項 骨䯣内血液循環状態の変化

血球増加の最も著明に認められた照射後 1 時間目にサイアシン灌流試験を行い，第 3 表， 及び第 3 図の如く骨髄内血流の促進を示した 阻ち No. 21 飞於ては曲線の山が 3 分, No. 22 に於ては 5 分に見られ，無処置家灾に就て行

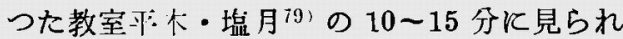
た山に比べれば明らかに左力に偏した。

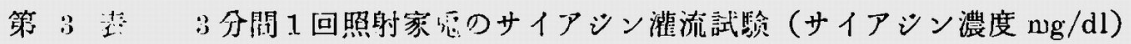

\begin{tabular}{r|l|l|l|l|l|l|l|l|l}
\hline \hline 侍 間 & \multicolumn{1}{c|c}{3 分 } & 5 & 10 & 15 & 20 & 30 & 45 & 60 & 90 \\
\hline No. 21 & 0.074 & 0.07 & 0.054 & 0.058 & 0.054 & 0.042 & 0.03 & 0 & 0 \\
No. 22 & 0.062 & 0.066 & 0.058 & 0.05 & 0.03 & 0.038 & 0.038 & 0 & 0
\end{tabular}

第: 3 図 3 分間 1 回照的家虑のサイア シン灌诋試䮖

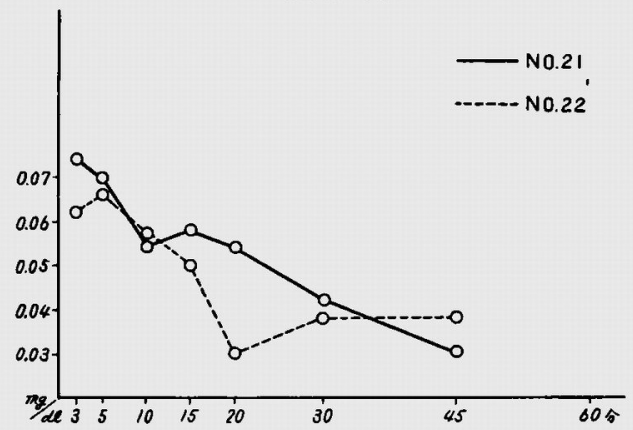

第了項 骨䯣組織所見

血球増加が最も著明であつた照射後 1 時間 目の骨䯣組織標本を検索したが，第 4 図の如 く認むべき造血機能の立進は無かつた。即ち 肾䯑通巨核球は 40 視野 ( $15 \times 100$ Tiyoda) 中, 9 個，10個，12個を数光，対照の10個，8 個, 12 個に比し大差なく，又実質細胞の稠密度， 静脈㕠内の血球充盈度等飞も著变を認めな い.

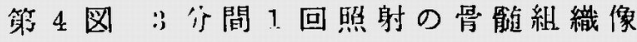

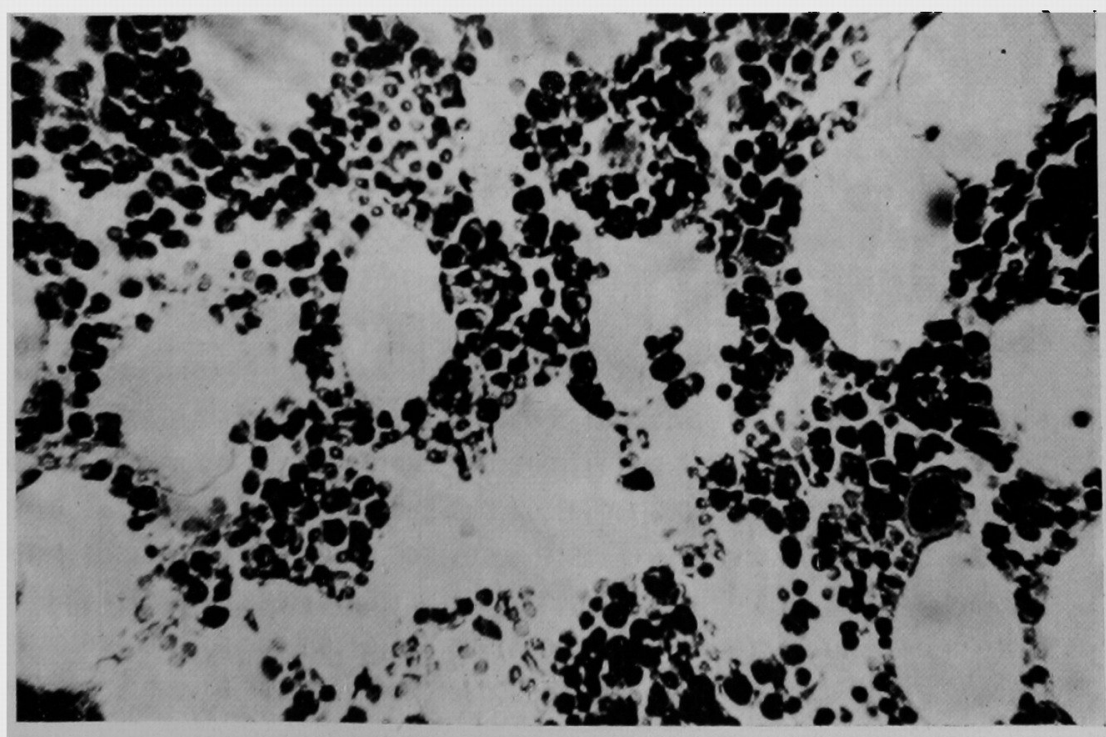


第 4 表 3 分閒連続照射せる場合の赤血 球系の変化

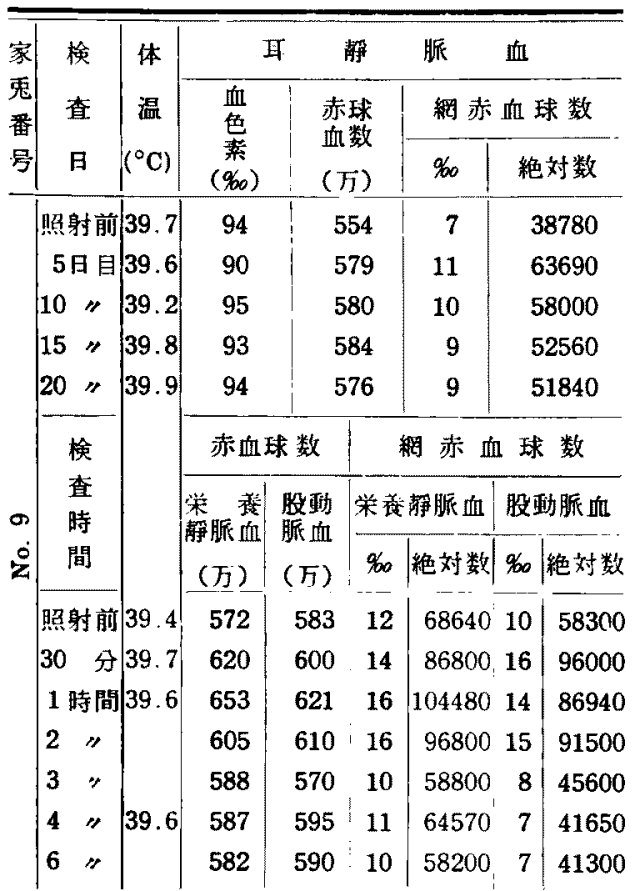

第 5 表 3 分間連続照射せる場合の浾血 球系の変化

\begin{tabular}{|c|c|c|c|c|c|c|c|c|}
\hline \multirow{3}{*}{$\begin{array}{l}\text { 家 } \\
\text { 愁 } \\
\text { 罚 } \\
\text { 号 }\end{array}$} & \multirow{3}{*}{$\begin{array}{c}\text { 検 } \\
\text { 查 } \\
\text { 日 }\end{array}$} & \multirow{3}{*}{$\left(\begin{array}{c}\text { 体 } \\
\text { 温 } \\
\left({ }^{\circ} \mathrm{C}\right)\end{array}\right.$} & \multicolumn{2}{|c|}{ 耳 } & 静 & 脈 & \multicolumn{2}{|l|}{ 血 } \\
\hline & & & \multirow{2}{*}{$\begin{array}{c}\text { 血 } \\
\text { 色 } \\
\text { 素 } \\
(\% 0) \\
\%\end{array}$} & \multirow{2}{*}{\multicolumn{2}{|c|}{$\begin{array}{l}\text { 赤球 } \\
\text { 血数 } \\
(\text { 万) }\end{array}$}} & \multicolumn{3}{|c|}{ 網赤血球数 } \\
\hline & & & & & & $\%$ & & 対数 \\
\hline \multicolumn{2}{|r|}{ 照射前 } & 39.4 & 80 & \multicolumn{2}{|c|}{590} & 8 & \multicolumn{2}{|c|}{47200} \\
\hline & 5日目 & 39.0 & 83 & \multicolumn{2}{|c|}{630} & 12 & \multicolumn{2}{|c|}{75600} \\
\hline & $10 \%$ & 39.0 & 77 & \multicolumn{2}{|c|}{587} & 6 & \multicolumn{2}{|c|}{35220} \\
\hline & 15 & 39.8 & 79 & \multicolumn{2}{|c|}{606} & 10 & \multicolumn{2}{|c|}{60600} \\
\hline & $20 "$ & 39.5 & 82 & \multicolumn{2}{|c|}{614} & 10 & \multicolumn{2}{|c|}{61400} \\
\hline & \multirow{3}{*}{$\begin{array}{l}\text { 㛟 } \\
\text { 查 } \\
\text { 時 } \\
\text { 間 }\end{array}$} & & \multicolumn{2}{|c|}{ 赤血 球数 } & \multicolumn{4}{|c|}{ 網 赤 血 球 数 } \\
\hline 익 & & & \multirow{2}{*}{ 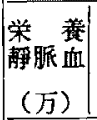 } & \multirow{2}{*}{$\begin{array}{l}\text { 股動 } \\
\text { 㟲血 } \\
\text { (万) }\end{array}$} & \multicolumn{2}{|c|}{ 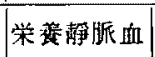 } & \multicolumn{2}{|c|}{ 股動脈血 } \\
\hline$\dot{0}$ & & & & & $\%$ & 絶対数 & $\%$ & 絶対数 \\
\hline & 照射前 & 39.6 & 599 & 611 & 11 & 65890 & 10 & 61100 \\
\hline & 30 分 & 39.6 & 646 & 620 & 19 & 122740 & 13 & 80600 \\
\hline & 1 時間 & 39.4 & 655 & 598 & 17 & 111350 & 16 & 95680 \\
\hline & $2 \%$ & & 660 & 646 & 16 & 105600 & 15 & 96900 \\
\hline & $3 \%$ & & 641 & 637 & 16 & 102560 & 15 & 95550 \\
\hline & $4 "$ & 39.9 & 600 & 580 & 10 & 60000 & 12 & 69600 \\
\hline & $6 "$ & & 615 & 590 & 10 & 61500 & 11 & 64900 \\
\hline
\end{tabular}

第 6 軎 3 i間連続照射せる場合の白血球系の変化

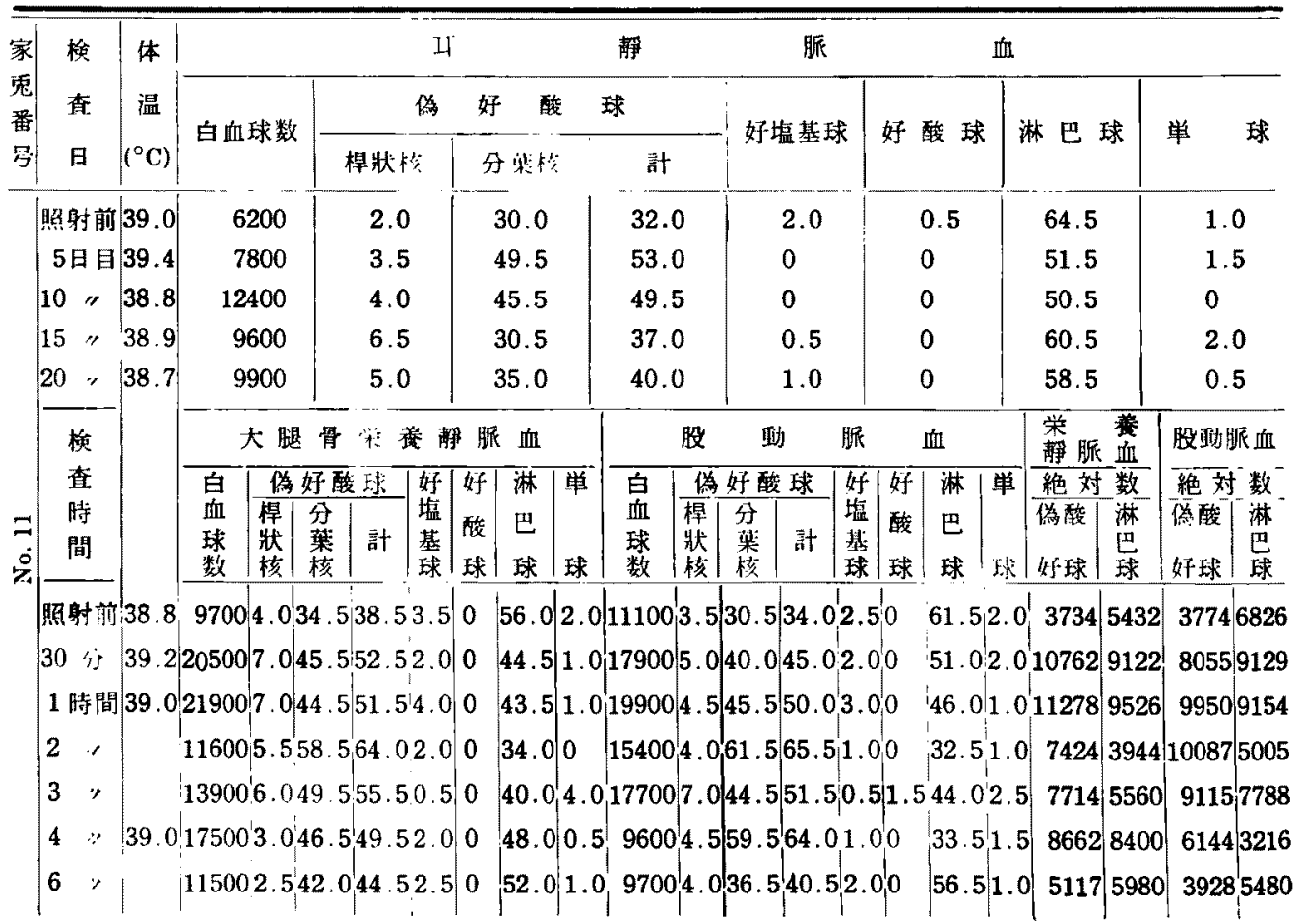


第 7 表 3 分間連続照射せる場合の白血球系の変化

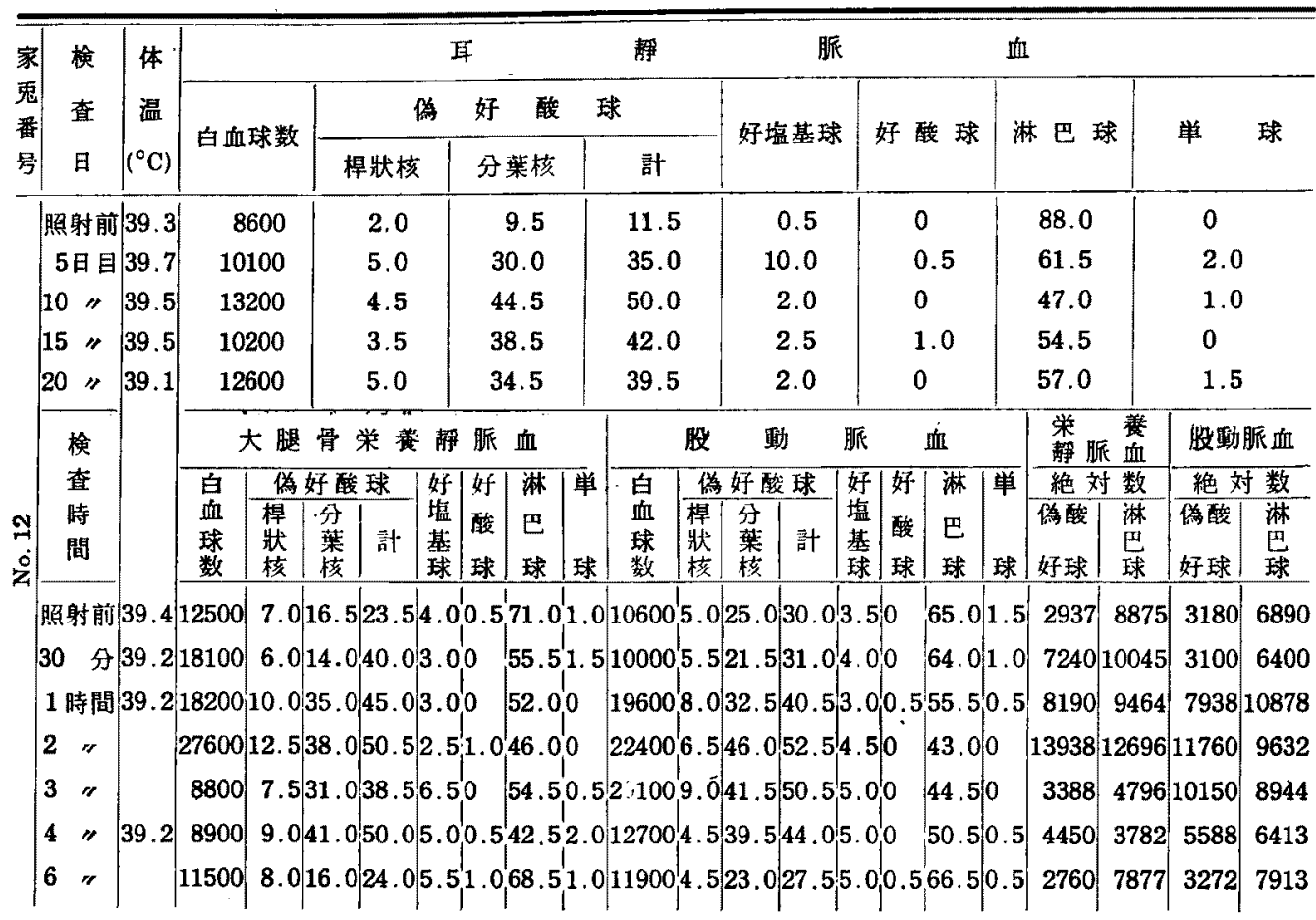

第 2 節 3 分間連続照射の場合

第 1 項 血液像の变化

3 分間照射を24時間間隔で20回照射した場 合の末梢血は，第 4 表及び第 5 表に示す如く， 血色素量飞は有意の差を見ないが，赤血球数 並飞網赤血球数は，No. 9 亿於ては 5 日目よ り軽度の增加を示し，No.10 亿於ても同様て あつた，白血球数は第 6 表及び第 7 表に示す 如く No. 11，No. 12 は共に 10 日目に最高值 （No. 11 は 100\%，No.12 は 53.4 名各增）を
示し，その百分比では核左方推移を伴 万偽好 酸球増加を見た，以後漸次隇少するる依然と

して照射前值に比し增加を示した。 次に20回目の照射に引続き，第 1 節に於け ると同様飞栄養静脈血像並飞股動脈血像を逐 時的仁検査し，その結果は第 3 表，第 4 表， 第 5 表，第 6 表，第 3 図，第 4 図に示した. 赤血球数は栄養静脈血，股動脈血共飞 30 分 後上り增加し， 1 時間乃至 2 時間後に最高值 （No. 9 の栄養静脈血では 11.496 股動脈血で

第 5 図 3 分間連続照射せる場合の赤血球系の変化

上段 赤血球数 下段 網赤血球数
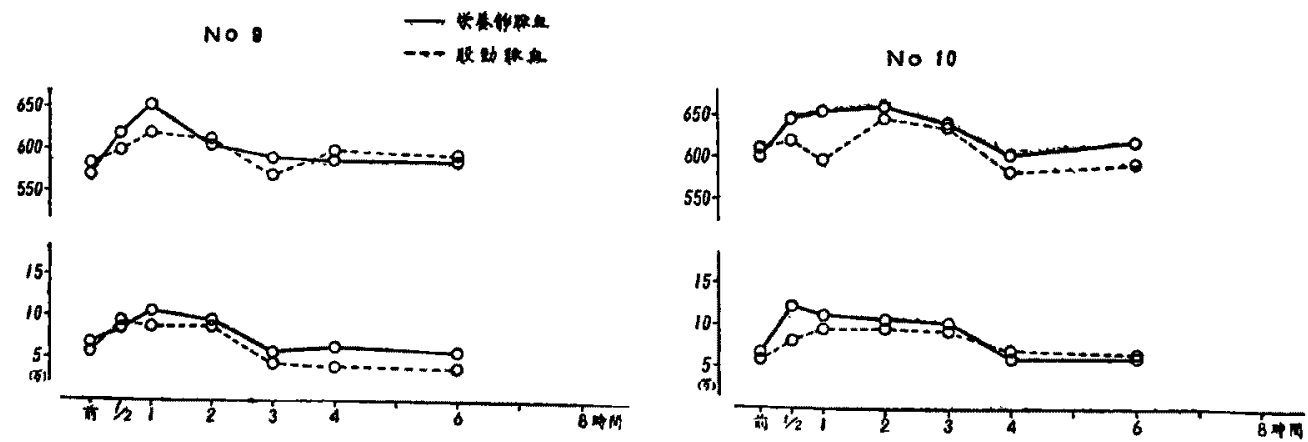
第 6 困 3 分間連続照射せる場合の白血球系の变化

上段 白血球数

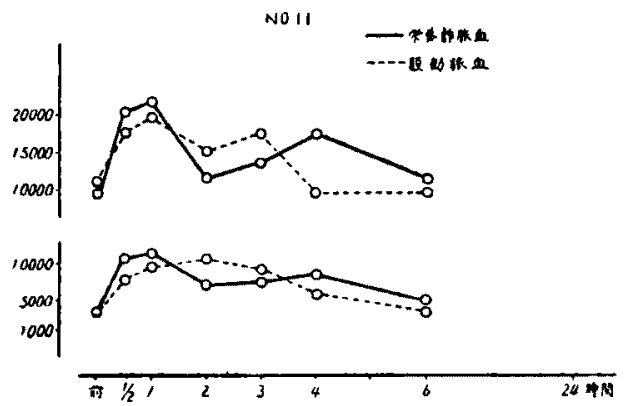

は 6.5\%, No. 10 では各々 $10.1 \%, 5.796$ 堌）飞達し，以後渐次減少して 3 万至 4 時間 後に旧に復した。

網赤血球数は赤血球数と略々平行して增減 し，30 分乃至 2 時間後飞最高值 (No. 9 の栄 素静脈血では 52.2\%，股動脈血では $64.6 \%$ ， No. 10 では各ஷ $86.2 \%, 58.5 \%$ 各增）飞達 した.

白血球数は栄責静脈血，股動脈血共飞照射 後 30 分より増加し， 1 乃至 2 時間後に最高 值 (No.11 の栄養静脈血では $111.3 \%$ ，股動 脈血では $79.2 \%$, No.12 では各々 $120.8 \%$, 111.396 各增）飞達し，以後漸次減少して 4 乃至 6 時間後に旧に復した．偽好酸球は，そ の百分比で軽度の核左方推移を伴う高度の增 多が見られ，その絶対数の最高值はNo.11の 栄養静脈血では202\%，股動脈血では167.2\%， No.12では各々374.5\%，269.8\%各增であり， その増減は白血球数のとれに略心平行すると
下段 偽好酸球数

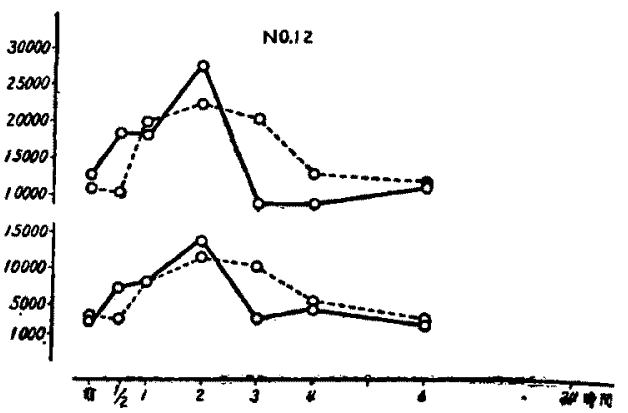

共にその主因をなす。

第 2 項 骨髄内血液循㻴状態の变化

20回目照射 1 時間後にサイアシン灌流試駼 を行い第 8 表，第 7 図の如く骨䯣内血流の促 進を示した. 即ち No. 23，No. 24 共に曲線の 山が 5 分に見られ教室平木・塩月79)の行つた 無処置家鬼に於ける山比へ明らか左方に 偏した。

符 7 図 3 分間連続照射家鬼のサイアシン 灌流試験

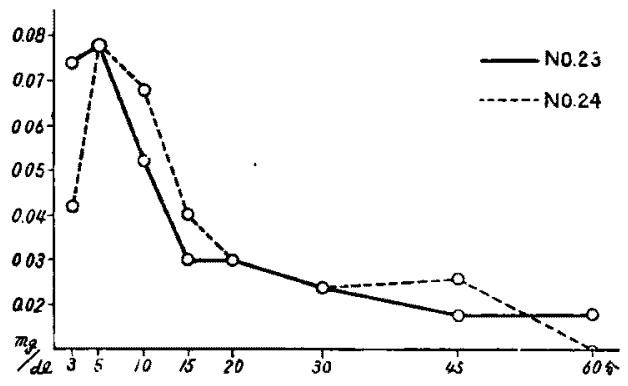

第 8 表 3 分間連続照射家鬼のサイアシン濩流試験（サイアシン濃度 $\mathrm{mg} / \mathrm{dl}$ )

\begin{tabular}{|c|c|c|c|c|c|c|c|c|c|}
\hline 家鬼番号—時 間 & 3 分 & 5 & 10 & 15 & 20 & 30 & 45 & 60 & 90 \\
\hline No. 23 & 0.074 & 0.078 & 0.052 & 0.03 & 0.03 & 0.024 & 0.018 & 0.018 & 0 \\
\hline No. 24 & 0.042 & 0.078 & 0.068 & 0.04 & 0.03 & 0.024 & 0.26 & 0 & 0 \\
\hline
\end{tabular}

第3 項 骨噵組織所見

20 回照射後の骨檤組織標本を検索した所, 第 8 因の如く骨髄巨核球は 40 視野 $(15 \times 100$, 干代田蝢微鏡）中，16個，14個，14個を数兄 軽度の增加を示し，実質細胞の稠密度も稍ぬ 高く軽度乍ら造血機能の亢進像を示した。
第了節 30 分間照射の場合

第 1 項 血球数の変化

1）赤血球数

栄養静脈血では第 9 表, 第 9 図の如く30分 間照射直後に於て最低值（No.13では19.6\%， No. 14 では25\%各減）飞達し, 以後濑次增加 
第 8 困 3 分間連続照的の骨䯣組織像

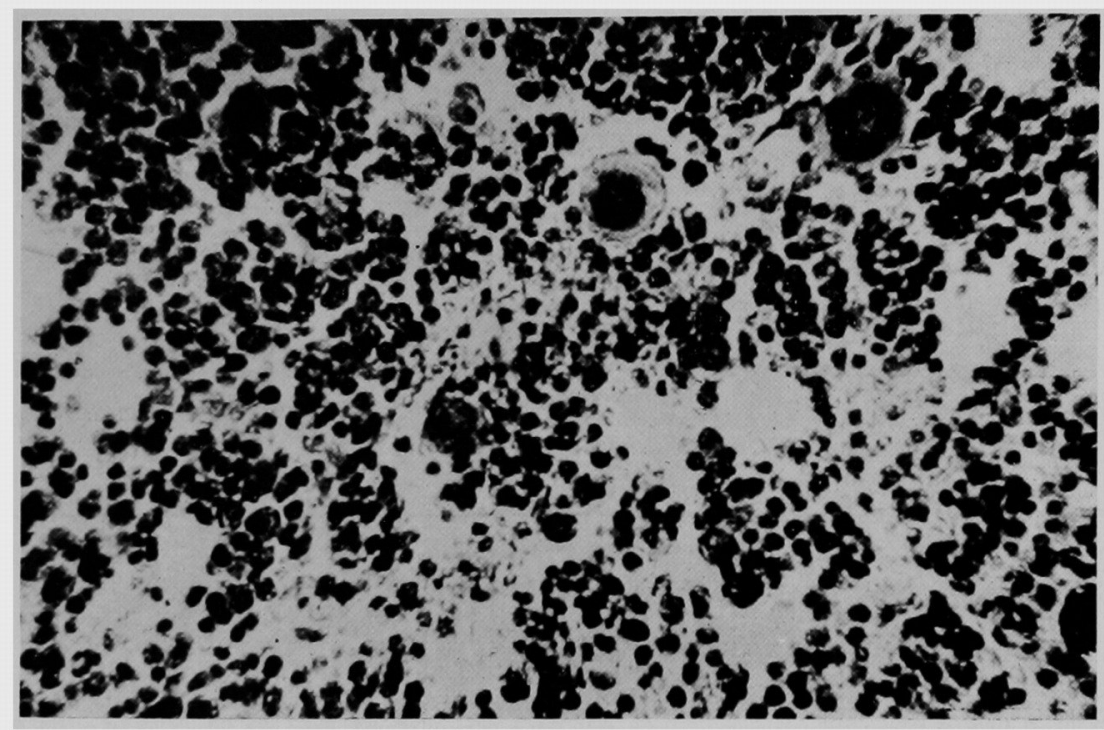

讶 9 表 30 分間照的せる場合の赤血球系 の変化

\begin{tabular}{|c|c|c|c|c|c|c|c|}
\hline \multirow{3}{*}{$\begin{array}{l}\text { 家 } \\
\text { 兔 } \\
\text { 罯 } \\
\text { 号 }\end{array}$} & \multirow{3}{*}{$\begin{array}{l}\text { 㮠 } \\
\text { if } \\
\text { 時 } \\
\text { 間 }\end{array}$} & \multirow{3}{*}{$\begin{array}{c}\text { 体 } \\
\text { 温 } \\
\left({ }^{\circ} \mathrm{C}\right)\end{array}$} & \multirow{3}{*}{ 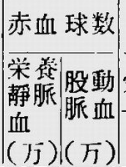 } & \multicolumn{4}{|c|}{ 網赤血球数 } \\
\hline & & & & \multicolumn{2}{|c|}{ 栄话静脈 血 } & \multicolumn{2}{|c|}{ 股動脈血 } \\
\hline & & & & 900 & 絶対数 & $\%$ & 絶対娄 \\
\hline \multirow{7}{*}{$\begin{array}{l}\text { No. } \\
13\end{array}$} & -1 & 39.5 & \begin{tabular}{l|l|}
460 & 477
\end{tabular} & 23 & 105800 & 19 & 9063 \\
\hline & atrif 你 & 40.8 & 370420 & 23 & 85100 & 18 & 560 \\
\hline & & 39.6 & 400411 & 26 & 104000 & 22 & 04 \\
\hline & 2 & & \begin{tabular}{l|l}
433 & 430
\end{tabular} & 19 & 82270 & 20 & 8600 \\
\hline & & & \begin{tabular}{l|l}
419 & 450
\end{tabular} & 24 & 100560 & 16 & 7216 \\
\hline & 4 & 39.6 & 502461 & 25 & 125500 & 23 & 10603 \\
\hline & $6 "$ & & \begin{tabular}{l|l}
490 & 491
\end{tabular} & 20 & 98000 & 20 & 9820 \\
\hline \multirow{8}{*}{ No. } & 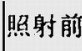 & 39. & $520 \mathrm{~b}$ & 1 & & & \\
\hline & 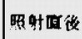 & & \begin{tabular}{l|l}
390 & 420
\end{tabular} & 13 & & & 80 \\
\hline & 1 時間 & 39.7 & $\begin{array}{lll}450 & 411\end{array}$ & 16 & 72000 & 15 & 165 \\
\hline & & & \begin{tabular}{l|l}
433 & 430
\end{tabular} & 17 & 610 & 13 & 590 \\
\hline & & & \begin{tabular}{l|l}
455 & 435
\end{tabular} & 14 & & 17 & 39 \\
\hline & & & \begin{tabular}{l|l}
502 & 460
\end{tabular} & 15 & & 1 & 532 \\
\hline & 0 & 39.9 & \begin{tabular}{l|l}
495 & 477
\end{tabular} & 18 & 9100 & 12 & 724 \\
\hline & & & \begin{tabular}{l|l}
490 & 501
\end{tabular} & 16 & 78400 & 15 & 7515 \\
\hline
\end{tabular}

し 4 時間後に旧に復し，股動脈血では栄養静 脈血より稍々遅れて照射後1時間に於て最低 值（N． 13 では 13.9\%，No.14では $20.6 \%$

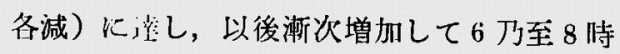
間後に旧に復した. 此の㥞に美養静脈血の変 化が股臐脈烅の変化飞先だつて生ずるとは注
吅 9 困 30分間照射せる場合の赤血球系 の変化

上段 尗血球数 下段 網赤血球数
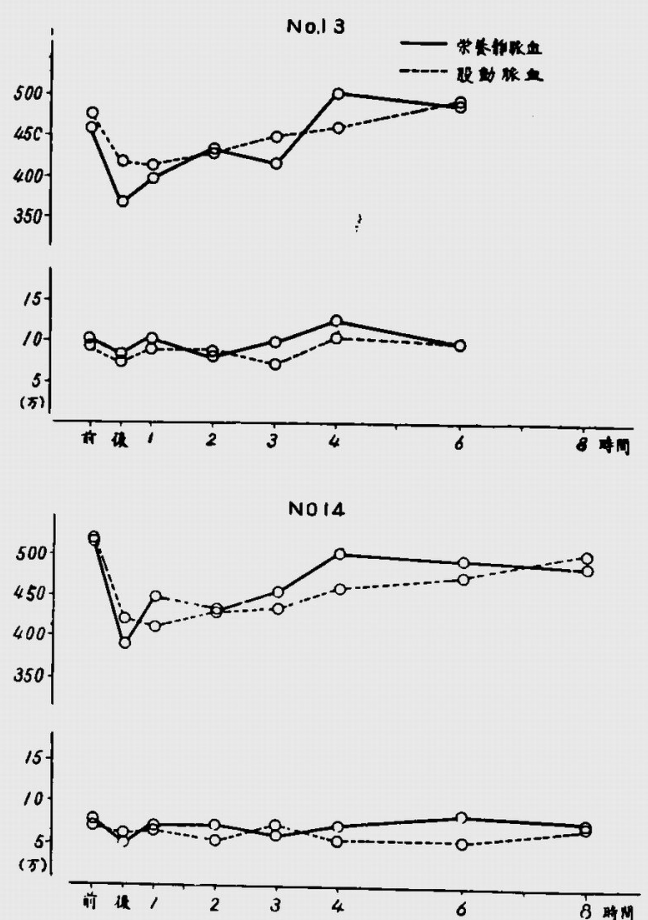

目すべきである。

2) 網永血球数

網尔侣球数は第 9 第 9 図の如く赤血球 
数と略々平行して减増するがその最低值は No. 13 の栄養静脈血では $23.3 \%$ ，股動脈血 では 20.4\%，No.14では各々 $35 \%$ \%, $23.6 \%$ 各減である。

3) 白血球数

栄養静脈血，股動脈血共飞第10表，第10図 の如く照射後 1 時間で最低值（No. 15 の策養 静脈血では $37 \%$ ，股動脈では $47.7 \% ， N o .16$ では各々 $20.9 \%, 25.1 \%$ 各減）飞達し，以後 漸次增加し 3 万至 6 時間後に至り旧值を越え
て増加し24時間後に旧に復した. 股動脈血飞 於ける減少率が栄養静脈血飞於けるそれより あ高くこれは注目すへきである，偽好酸球絶 対数照射直後No.15の栄養静脈血では13.6 $\%$ ，股動脈血では $35.6 \% ，$ No. 16 では各々 $41 \%, 25.1 \%$ 減少を示し, No. 15の栄養静 脈血では 6 時間後飞 $150.4 \%$ ，股動脈血では 同じく 6 時間後飞 $25.5 \%$, No. 16 の栄養静脈 血では，3 時間後飞 $122.6 \%$ ，股動脈血では 同じく3 時間後飞 $204.4 \%$ の增加を示し 24 時

第 10 表 30 分間照射せる場合の白血球系の変化

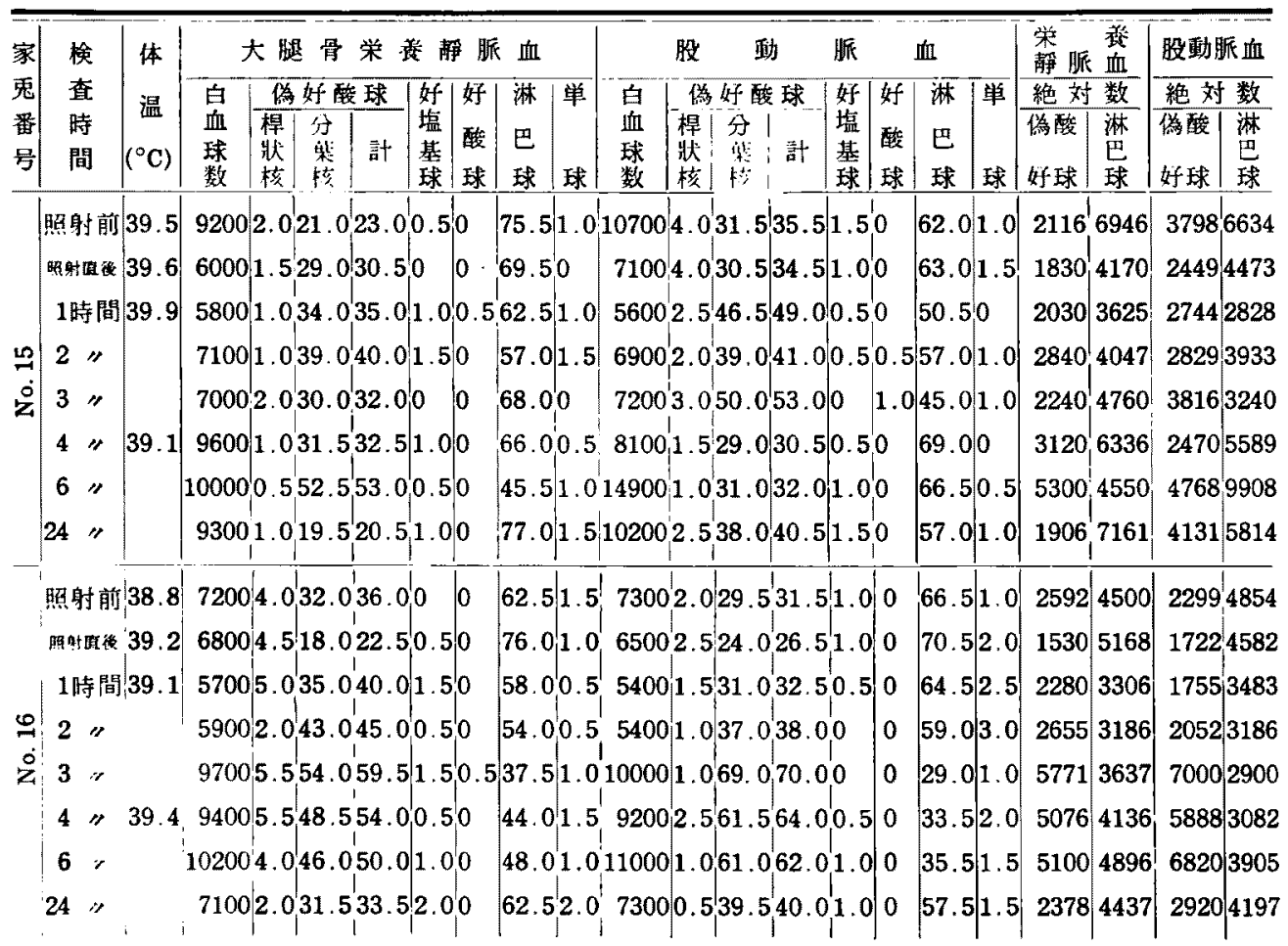

第10図 30 分間照射せる場合の白血球系の变化

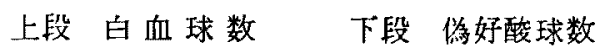
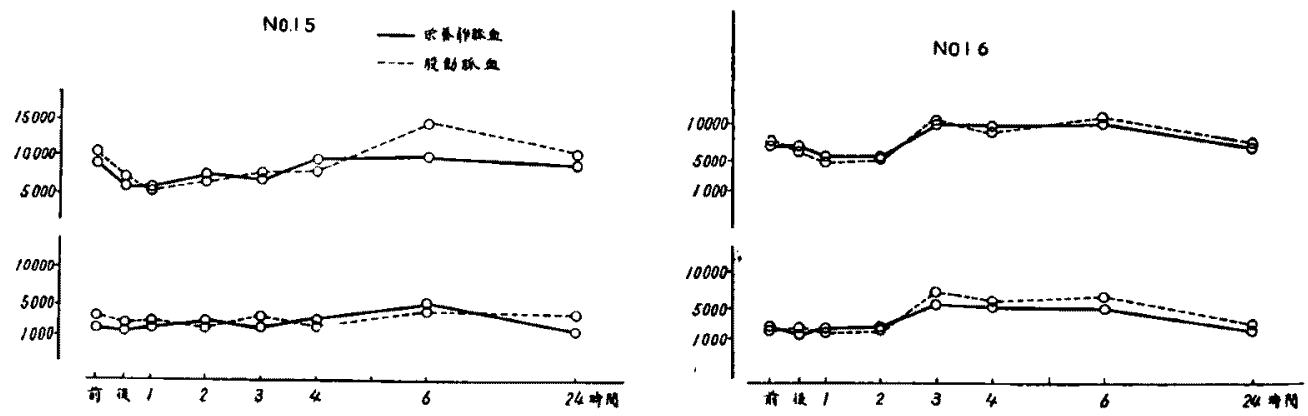
間後に旧に復した。

第 2 項 骨髄内血液循環状態の変化

血球減少の最も著明に認められた 30 分間照 射直後にサイアジン灌流試験を行い，第11表，
第 11 図の如〈教室平木・塩月79) が無処置家 覀に於て得た様な山を見ず，骨髄内血流の遅 延を認めた。

第 11 表 30 分間照射家兔のサイアシンン灌流試験（サイアジン濃度 $\mathrm{mg} / \mathrm{dl}$ ）

\begin{tabular}{c|c|c|c|c|c|c|c|c|c}
\hline \hline 家鬼番号 間! & 3 分 & 5 & 10 & 15 & \multicolumn{1}{|c|}{20} & 30 & 45 & 60 & 90 \\
\hline No. 25 & 0.032 & 0.042 & 0.042 & 0.054 & 0.05 & 0.054 & 0.042 & 0.03 & 0 \\
No. 26 & 0.042 & 0.032 & 0.038 & 0.042 & 0.05 & 0.03 & 0.042 & 0 & 0
\end{tabular}

第11図 30分間照射家秉のサイアシン 灌流試験

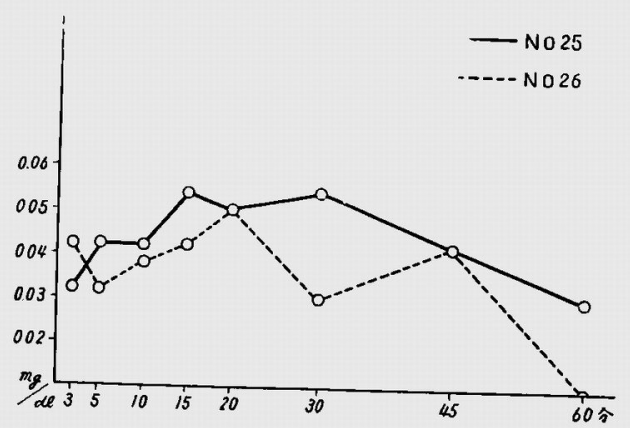

第了項 骨䯣組織所見

30 分間照射直後の骨䯣組織標本を検索し, 第 12 図の如く骨䯣巨核数は40視野（15×100, 千代田顕微鏡）中 10 個，9 個，10 個を数光， 実質細胞の稠密度も対照と著変なく，造血機 能に変化を認めなかつたが，静脈泳の充血像 がかなり認められ血球の抑留を思わせるに充 分であつた。

第 4 節 鉤虫症血清灌流後の 3 分閆 照射

第 1 項 血球数の変化

1) 赤血球数

第 12 図 30 分間照射の骨䯣組織像

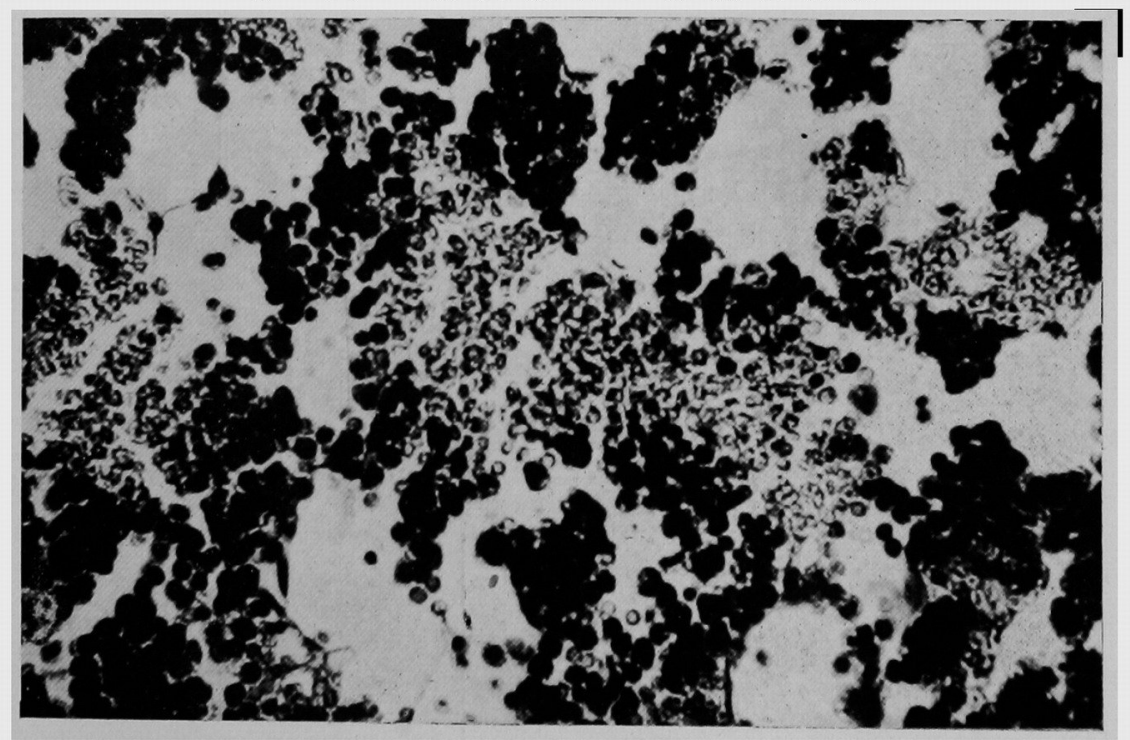

鉤虫症患者血清灌流後 3 分間照射を行えば, 血清のみの灌流飞比し栄養静脈血の赤血球減 少は軽度であり，更にとの回復も早い，即ち 第 12 表，第 13 図の如く栄養静脈血では，照
射後減少を始め 1 時間後に最低（No. 17 では $8.5 \%$ ，No. 18 では $5.3 \%$ 各減）となり，以 後漱增し思に $21 / 2$ 恃間後に旧に復し，教䇪 藤田 ${ }^{84)}$ の血清のみの櫵流奏験飞於ける減少率 
第12表 鈎虫症血清濩流後 3 分間照射女 る場合の㑐血球系の変化

\begin{tabular}{|c|c|c|c|c|c|c|c|}
\hline \multirow{3}{*}{$\begin{array}{l}\text { 家 } \\
\text { 兏 } \\
\text { 番 } \\
\text { 号 }\end{array}$} & \multirow{3}{*}{$\begin{array}{l}\text { 検 } \\
\text { 查 } \\
\text { 時 } \\
\text { 間 }\end{array}$} & \multirow{3}{*}{$\left|\begin{array}{c}\text { 体 } \\
\text { 温 } \\
\left({ }^{\circ} \mathrm{C}\right)\end{array}\right|$} & \multirow{3}{*}{ 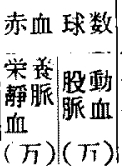 } & \multicolumn{4}{|c|}{ 䑪赤 血 球 数 } \\
\hline & & & & \multicolumn{2}{|c|}{ 栄鼠啨脈血 } & \multicolumn{2}{|c|}{ 股動脈血 } \\
\hline & & & & $\%_{\infty}$ & 絶対数 & $\%$ & 絶対数 \\
\hline \multirow{9}{*}{$\begin{array}{r}\text { No. } \\
17\end{array}$} & 拄人剖 & 39.2 & 450462 & 20 & 90000 & 24 & 110880 \\
\hline & 1/2時間 & 39.0 & 438 & 20 & 87600 & 24 & 113040 \\
\hline & $1 \pi$ & 39.6 & \begin{tabular}{l|l|}
412 & 480
\end{tabular} & 22 & 90640 & 26 & 124800 \\
\hline & $11 / 2$ & & \begin{tabular}{l|l|}
423 & 472 \\
\end{tabular} & 20 & 84600 & 24 & 113280 \\
\hline & 2 & & 421 & 21 & 88410 & 25 & 120500 \\
\hline & $21 / 2$ & & \begin{tabular}{l|l|}
472 & 487
\end{tabular} & 21 & 99120 & 25 & 121750 \\
\hline & 3. & & $\begin{array}{ll}462 & 475\end{array}$ & 23 & 106260 & 26 & 123500 \\
\hline & $4 \%$ & 39.8 & $\begin{array}{lll}455 & 466\end{array}$ & 20 & $91000^{\prime}$ & 25 & 116500 \\
\hline & $6 \%$ & & 440,459 & 22 & 96800 & 24 & 110160 \\
\hline \multirow{9}{*}{$\begin{array}{r}\text { No. } \\
18\end{array}$} & 注入前 & 39. & $650.639 \mid$ & 16 & $104000 \mid$ & 18 & 115020 \\
\hline & $1 / 2$ 時間 & 38,8 & 635650 & 17 & 107950 & 18 & 117000 \\
\hline & $1 "$ & 38.6 & $616 \quad 621$ & 15 & 92400 & 19 & 117990 \\
\hline & $11 / 2:$ & & $\begin{array}{ll}620 & 641\end{array}$ & 17 & 105400 & 20 & 128200 \\
\hline & $2 "$ & & $620 \quad 633$ & 18 & 111600 & 20 & 126600 \\
\hline & $21 / 2 "$ & & $654 \quad 634$ & 16 & 104640 & 17 & 107780 \\
\hline & $3 \pi$ & & $644 \quad 635$ & 16 & 103040 & 18 & 114300 \\
\hline & 4 & 38.8 & 669647 & 19 & 127110 & 21 & 135870 \\
\hline & $"$ & & 655645 & 17 & $111350^{\prime}$ & 20 & 129000 \\
\hline
\end{tabular}

$16.7 \%$ ，减少回復時間 4 時間に比し有意の差 を示した。

\section{2）網赤血球数}

網尔血球数は第12袁，第13図に示す如くそ の干分比飞著変無く，絶対数に於ては No. 18 の栄養静脈血で 1 月细倸に11.2\%の減少を見 る外，著しい増減を認めないが，全観察時間 を通じ股動脈血に於ける絶対数が優位を寺し

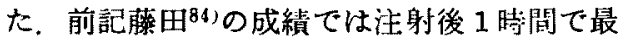
低（17.8\%減）となり6乃至 8 時間で旧に復 しているがここれに比すれば仗験による絶 対数の減少は軽度であり，回復㭙間も短く回 復後はかえつて增加の倾向を示した．

3) 白血球数

白血球数は第 13 表，第 14 因の如く栄養 静脈血では照射谖30们乃至 1 㭙間で最低䛧 (No.19 では $12.9 \%$, No.20では 8.5\%各減) K達し，以後回復し $1 \frac{1}{2}$ 将間後はかえつて增

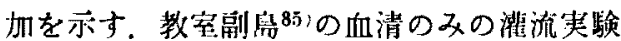

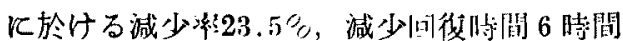

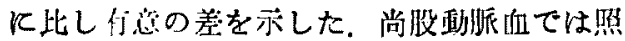

第13図 鉤虫症血清灌流後 3 分間照射 せる場合の赤血球系の変化 上段 赤血 球数 下段 網赤血球数
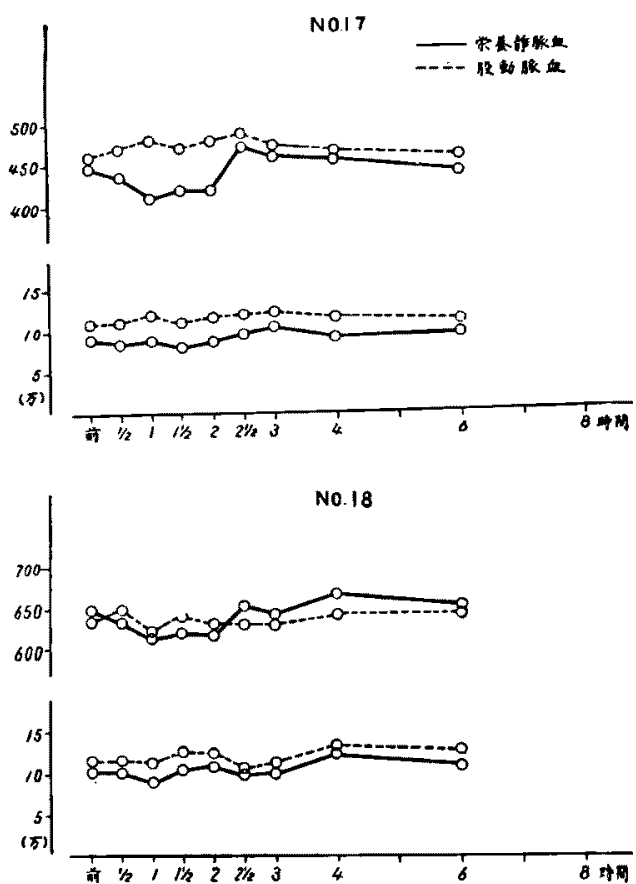

第14図 鈎虫症血清灌流後 3 分間照射世る 場合の白血球系の変化

上段 白血球数 下段 偽好酸球数
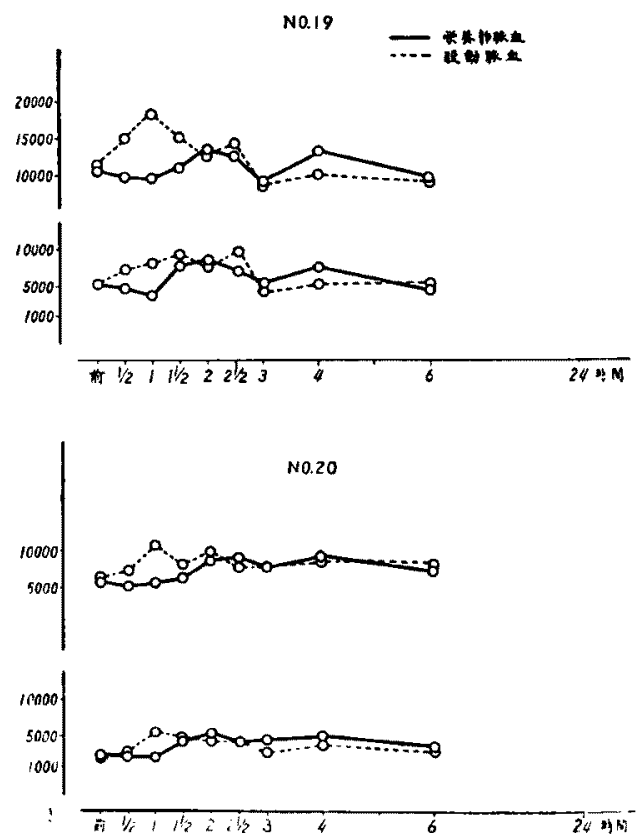
第 13 表 鈎虫症血清灌流後 3 分間照射せる場合の白血球系の変化

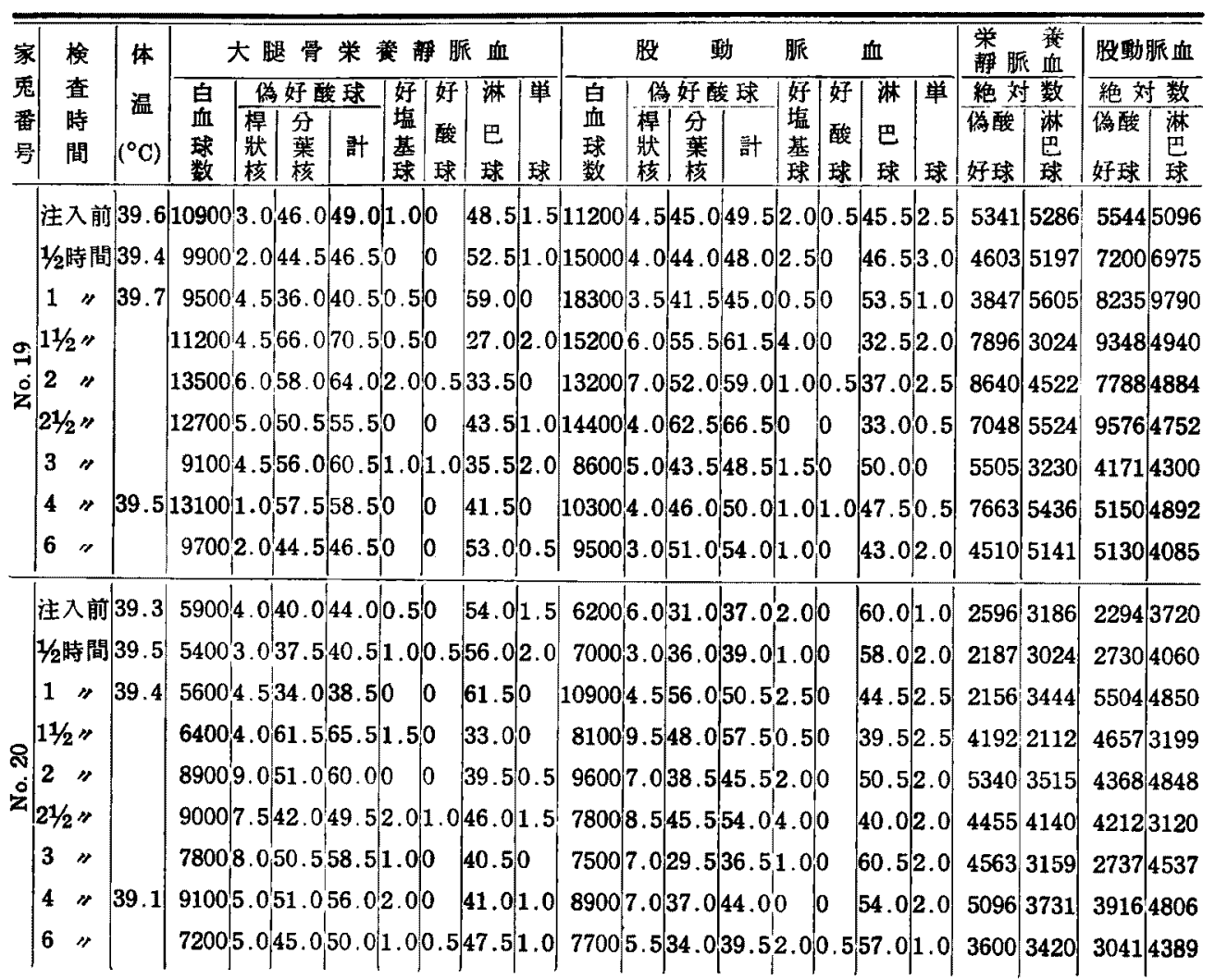

射後増加し，1時間後に最高值（No.19では 63.3\%，No. 20 では 75.8 \%各增）飞達し， 以後漸次旧に復した。

偽好酸球は举養静脈血，股動脈血共に白血 球数汗平行して增減し白血球数增減の主因と なる。即ち栄营静脈血では 1 時間後に最低值 (No.19では28\%，No.20では17\%各減）火 達するる以後增加し 2 時間後に最高值 (No.19 では $61.7 \%$ ，No. 20 では $105.7 \%$ 各增）を 示し, 渐次旧飞復した。

第 2 項 骨髄内血液循環状態の変化 鈎虫症患者血清灌流後 3 分間照射を行い， 照射後 1 時間目にサイアシン灌流試験で骨䯣 内血流を検した所，第14表，第15図の如くで
教室藤井 ${ }^{85}$ )の該血清のみの灌流時飞於ける血 流遅延は見られず，教室平木・塭月79》の無処 置家鬼に於ける成績と同㥞であつた。

\section{第15図 鈎虫症血清灌流家鬼の} サイアシン灌流試験

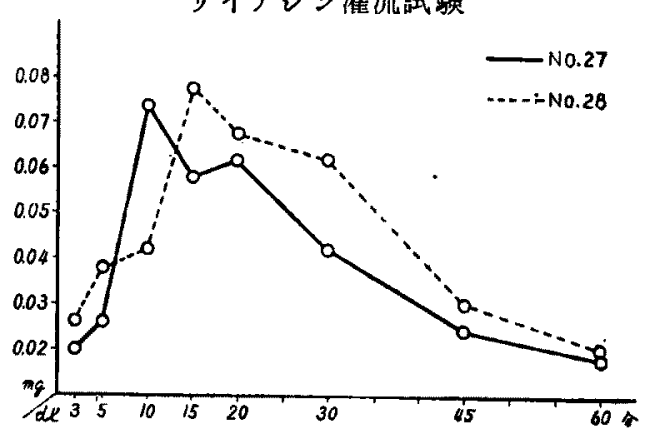

第 14 表 銁虫症血清濩流家鬼のサイアシン韲流試験（サイアシン濃度 $\mathrm{mg} / \mathrm{dl}$ ）

\begin{tabular}{c|c|c|c|c|c|c|c|c|c}
\hline \hline 家鬼番是 & 3 & 5 & 10 & 15 & 20 & 30 & 45 & 60 & 90 \\
\hline No. 27 & 0.02 & 0.026 & 0.074 & 0.058 & 0.062 & 0.042 & 0.024 & 0.018 & 0 \\
No. 28 & 0.026 & 0.038 & 0.042 & 0.078 & 0.068 & 0.062 & 0.03 & 0.02 & 0
\end{tabular}


第 5 節 骨䯣体外組織培養への影響

第 1 項 比較成長価飞及ぼす影響

1) 3 分間 1 回照射の場合

3 分間照射直後及び 2 時間後仿於ては，第 15 表，第16表飞示守如く比較成長価飞有意の 差を認めなかつた。

第15表 3 分間照射直後の比輘成長価

\begin{tabular}{|c|c|c|c|c|c|}
\hline 家兔番号 侍間 & 3 & 6 & 12 & 24 & 48 \\
\hline No. 80 & 12.32 & 18.90 & 25.10 & 34.42 & \\
\hline No. 81 & 12.31 & 18.90 & 25.01 & 34.41 & 51.44 \\
\hline No. 82 & 12. 32 & 18.90 & 25.01 & 34.32 & 51.40 \\
\hline No: 83 (対照) & 12.35 & 18.92 & 25.06 & 34.40 & 51.46 \\
\hline
\end{tabular}

第16表 3 分間照射 2 時間後の比較成長価

\begin{tabular}{l|r|r|c|c|c}
\hline \hline 家鬼番号 時間 & \multicolumn{1}{|c|}{3} & \multicolumn{1}{|c|}{6} & 12 & 24 & 48 \\
\hline No. 84 & 5.36 & 8.87 & 19.17 & 24.62 & 38.66 \\
No.85 & 7.41 & 10.56 & 19.70 & 24.14 & 37.75 \\
No. 86 & 6.49 & 11.02 & 22.31 & 30.73 & 40.51 \\
No.87 (対照) & 6.38 & 10.58 & 21.40 & 29.71 & 39.14
\end{tabular}

3 分間照射 24 時間後飞於ては，第17表，第 16図に示与如く対照飞比し增生は著明に元進 していた.

第17表 3 分間照射 24 時間後の比較成長価

\begin{tabular}{l|r|c|c|c|c}
\hline \hline 家鬼番号 & \multicolumn{1}{|c|}{3} & \multicolumn{1}{c|}{6} & 12 & 24 & 48 \\
\hline No. 88 & 10.14 & 14.28 & 20.10 & 36.95 & 42.19 \\
No. 89 & 8.65 & 17.67 & 24.42 & 42.88 & 46.40 \\
No. 90 & 10.31 & 17.90 & 23.67 & 29.86 & 33.09 \\
No. 91 (対照) & 6.38 & 10.58 & 14.23 & 19.81 & 26.09
\end{tabular}

第16図 3 分間照射 24 時間後の比較成長価

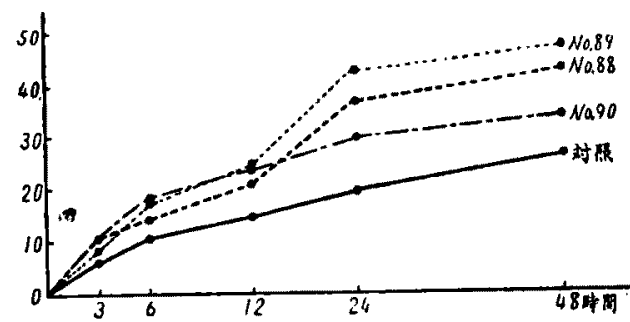

3 分間照射 48 時間及び 72 時間後に於ては 第 18 表，第 19 表飞示す如く何れも有意の差 を認めなかつた。
第18表 3 分間照射48時間後の比較成長価

\begin{tabular}{l|c|c|c|c|c}
\hline \hline 家鬼番号 & 3 & 6 & 12 & 24 & 48 \\
\hline No. 92 & 4.81 & 8.39 & 17.58 & 25.46 & 30.21 \\
No. 93 & 4.92 & 8.42 & 17.87 & 25.42 & 30.04 \\
No. 94 & 4.76 & 8.35 & 18.04 & 25.52 & 30.04 \\
No. 95 (対照) & 4.80 & 8.37 & 18.02 & 25.42 & 30.03
\end{tabular}

第19表 3 分間照射 72 時間後の比較成長価

\begin{tabular}{|c|c|c|c|c|c|}
\hline 家鬼番号 時間 & 3 & 6 & 12 & 24 & 48 \\
\hline No. 96 & 6.32 & 11.43 & 15.02 & 19.12 & 25.15 \\
\hline No. 97 & 7.21 & 11.22 & 14.79 & 19.90 & 27.66 \\
\hline No. 98 & 6.44 & 10.60 & 14.36 & 19.04 & 26.24 \\
\hline No.99（対照） & 6.38 & 10.58 & 14.23 & 19.81 & 26.09 \\
\hline
\end{tabular}

2）3 分間10日連続照射の場合

3 分間10日連続照射例では第20表, 第17図 に示拁く増生は 3 例中 2 例飞於て, 稍々元 進し他の1例は対照より稍タ低值を示した。

第20表 3 分間10日連続照射の比較成長価

\begin{tabular}{l|c|c|c|c|c}
\hline \hline 家鬼番号 時間 & 3 & 6 & 12 & 24 & 48 \\
\hline No. 100 & 4.68 & 9.01 & 24.36 & 32.55 & 45.36 \\
No. 101 & 4.81 & 8.47 & 24.38 & 32.70 & 45.05 \\
No. 102 & 4.10 & 7.98 & 20.38 & 28.01 & 40.65 \\
No. 103(対照) & 4.14 & 8.10 & 21.84 & 29.92 & 42.66 \\
\multicolumn{1}{|l}{}
\end{tabular}

第17図 3 分間10日連続照射の比暧成長価

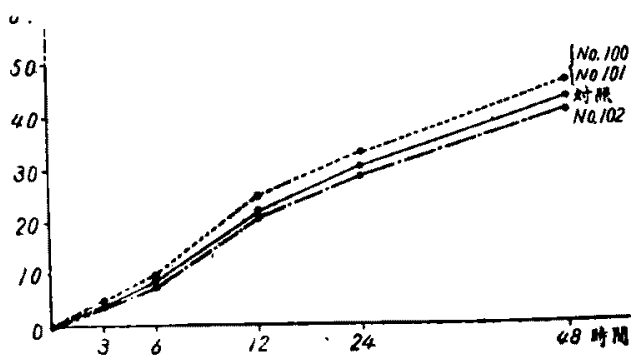

3） 3 分間20日連続照射の場合 3 分間20日連繶照射例では第21表, 第18図 に示す如く 3 例中 2 例憎生の亢進を示し他 の1例は対照と殆んど同値であつた。

4） 30 分間照射の場合30分間照射直後24時 間後48時間後飞於ては，第22表，第23表，第 24表に示す如く增生に有意の差を認めなかつ た. 
第21表 3 分間20日連続照射の比較成長価

\begin{tabular}{l|c|c|c|c|c}
\hline \hline 家鬼番号 & 3 & 6 & 12 & 24 & 48 \\
No. 104 & 4.79 & 9.01 & 23.24 & 32.35 & 45.63 \\
No. 105 & 4.22 & 9.10 & 22.52 & 32.30 & 45.03 \\
No. 106 & 4.12 & 8.08 & 21.82 & 29.70 & 42.06 \\
No. 107(対照) & 4.14 & 8.10 & 21.84 & 29.92 & 42.66
\end{tabular}

第18図 3 分間20日連続照射の比較成長価

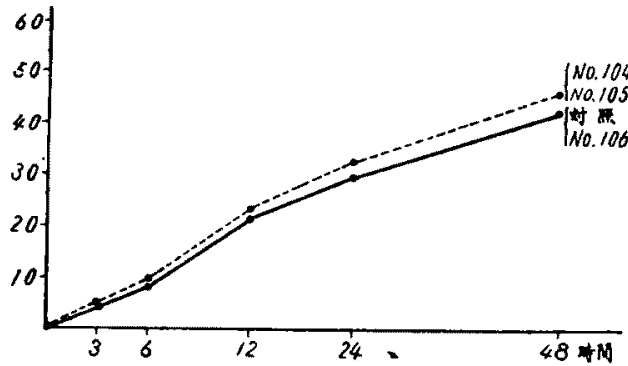

第22表 30 分間照射直後の比較成長洒

\begin{tabular}{|c|c|c|c|c|c|}
\hline 家鬼番号 & 3 & 6 & 12 & 24 & 48 \\
\hline No. 108 & 4.31 & 7.97 & 16.88 & 24.24 & 30.10 \\
\hline No. 109 & 4.63 & 8.11 & 16.85 & 24.38 & 30.02 \\
\hline No. 110 & 4.72 & 8.99 & 18.24 & 26.45 & 30.80 \\
\hline No. 111 (対照) & 4.62 & 8.63 & 17.94 & 25.56 & 30.21 \\
\hline
\end{tabular}

第23表 30 分間照射 24 時間後の比較成長価

\begin{tabular}{|c|c|c|c|c|c|}
\hline 家鬼番号 時間 & 3 & 6 & 12 & 24 & 48 \\
\hline No. 112 & 4.80 & 8.89 & 16.79 & 23.84 & 28.31 \\
\hline No. 113 & 4.89 & 8.92 & 16.81 & 24.04 & 29.42 \\
\hline No. 114 & 4.76 & 9.01 & 18.23 & 26.42 & 31.52 \\
\hline No. 115（対照） & 4.62 & 8.63 & 17.94 & 25.56 & 30.21 \\
\hline
\end{tabular}

第24表 30 分間照射 48 時間後の比較成長価

\begin{tabular}{|c|c|c|c|c|c|}
\hline 家鬼番号 時間 & 3 & 6 & 12 & 24 & 48 \\
\hline No. 116 & 4.56 & 8.29 & 17.85 & 25.18 & 30.00 \\
\hline No. 117 & 4.75 & 8.30 & 17.97 & 25.36 & 30.00 \\
\hline No. 118 & 4.87 & 8.90 & 16.80 & 24.00 & 28.38 \\
\hline No.119（刘照） & 4.62 & 8.63 & 17.94 & 25.56 & 30.21 \\
\hline
\end{tabular}

第 2 項 像好酸球遊走速度に及に゙す影響

1） 3 分間 1 回照射の場合

3 分間照射直後及び 2 時間後飞於ては，第 25表，第26表《示す如く有意の差を認めなか つた。 3 分間照射24時間後飞於ては第27表,
第25表 3 分間照射直後の遊走速度 (偽好酸球) $\mu / \mathrm{min}$.

\begin{tabular}{|c|c|c|c|c|c|}
\hline 家鬼番号 時間 & 3 & 6 & 12 & 24 & 48 \\
\hline No. 80 & 13.70 & 11.64 & 6.42 & 4.62 & 2.26 \\
\hline No. 81 & 13.79 & 11.66 & 6.41 & 4.56 & 2.44 \\
\hline No. 82 & 13.64 & 11.60 & 6.11 & 4.10 & 2.20 \\
\hline No. 83 (対照) & 13.71 & 11.62 & 6.23 & 4.12 & 2.23 \\
\hline
\end{tabular}

第26表 3 分間照射 2 時間後の遊走速度 (偽好酸球) $\mu / \mathrm{min}$.

\begin{tabular}{|c|c|c|c|c|c|}
\hline 家鬼番号 & 3 & 6 & 12 & 24 & 48 \\
\hline No. 84 & 13.15 & 13.15 & $9.47^{\prime}$ & 4.21 & 3.15 \\
\hline No. 85 & 11.57 & 7.89 & 6.31 & 3.68 & 3.21 \\
\hline No. 86 & 13.41 & 9.26 & 8.03 & 3.59 & 3.81 \\
\hline No. 87 (対照) & 13.68 & 8.94 & 7.89 & 3.15 & 3.68 \\
\hline
\end{tabular}

第27表 3 分間照射 24 時間後の遊走速度 (偽好酸球) $\mu / \mathrm{min}$.

\begin{tabular}{|c|c|c|c|c|c|}
\hline 家鬼番号 時間 & 3 & 6 & 12 & 24 & 48 \\
\hline No. 88 & 14.21 & 9.29 & 8.42 & 4.02 & 4.12 \\
\hline No. 89 & 10.52 & 9.47 & 8.42 & 4.10 & 3.92 \\
\hline No. 90 & 10.00 & 11.05 & 8.92 & 5.01 & 4.73 \\
\hline No. 91 (対照) & 13.68 & 8.94 & 7.89 & 3.15 & 3.68 \\
\hline
\end{tabular}

第19図 3 分間照射24時間直後の遊走

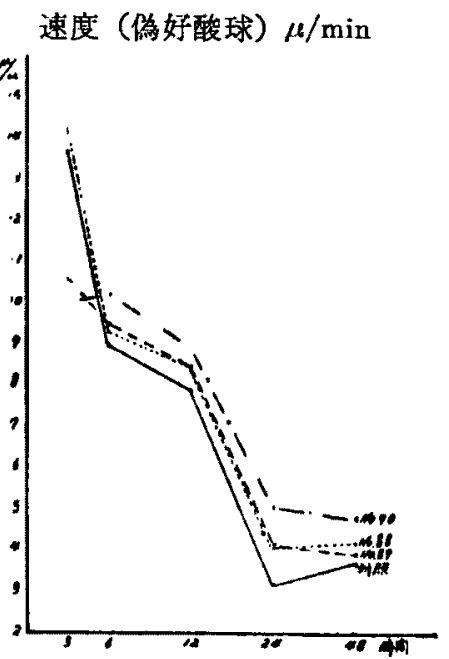

第19図に示す如く遊走速度は明らかに元進し ていた.

3 分間照射 48 時間及び72時間後に於ては第 28表，第29秦に示す如く有意の养は認められ 
第28表 3 分間照射 48 㭙間後の遊走速度 （偽好酸球） $\mu / \mathrm{min}$.

\begin{tabular}{|c|c|c|c|c|c|}
\hline 家鬼番号 时間 & 3 & 6 & 12 & 24 & 48 \\
\hline No. 92 & 12.11 & 12.12 & 8.32 & 6.22 & 4.01 \\
\hline No. 93 & 13.11 & 12.19 & 8.34 & 6.20 & 4.10 \\
\hline No. 94 & 11.92 & 11.41 & 8.11 & 6.04 & 3.92 \\
\hline No. 95 (対照) & 12.72 & 12.01 & 8.30 & 6.11 & 3.94 \\
\hline
\end{tabular}

第29表 3 分間照射72時間後の遊走速度

(偽好酸球) $\mu / \mathrm{min}$.

\begin{tabular}{|c|c|c|c|c|c|}
\hline 家鬼番号 時間 & 3 & 6 & 12 & 24 & 48 \\
\hline No. 96 & 13.96 & 11.01 & 6.46 & 4.01 & 2.02 \\
\hline No. 97 & 13.86 & 10.96 & 6.64 & 4.10 & 2.06 \\
\hline No. 98 & 13.64 & 10.90 & 6.66 & 4.12 & 2.18 \\
\hline No. 99 (対照) & 13.68 & 8.94 & 7.89 & 3.15 & 3.68 \\
\hline
\end{tabular}

第30表 3 分間10日連続照射の遊走速度 (偽好酸球) $\mu / \mathrm{min}$.

\begin{tabular}{l|c|c|c|c|c}
\hline \hline 家鬼番号 & 3 & 6 & 12 & 24 & 48 \\
No. 100 & 12.40 & 12.10 & 9.22 & 7.04 & 5.03 \\
No. 101 & 12.66 & 12.10 & 9.11 & 6.99 & 4.69 \\
No. 102 & 11.37 & 11.19 & 8.20 & 6.18 & 3.92 \\
No. 103(対照) & 11.36 & 11.21 & 8.21 & 6.12 & 3.92
\end{tabular}

第20因 3 分間10日連絖照射の遊走速度

(偽好酸球) $\mu / \mathrm{min}$

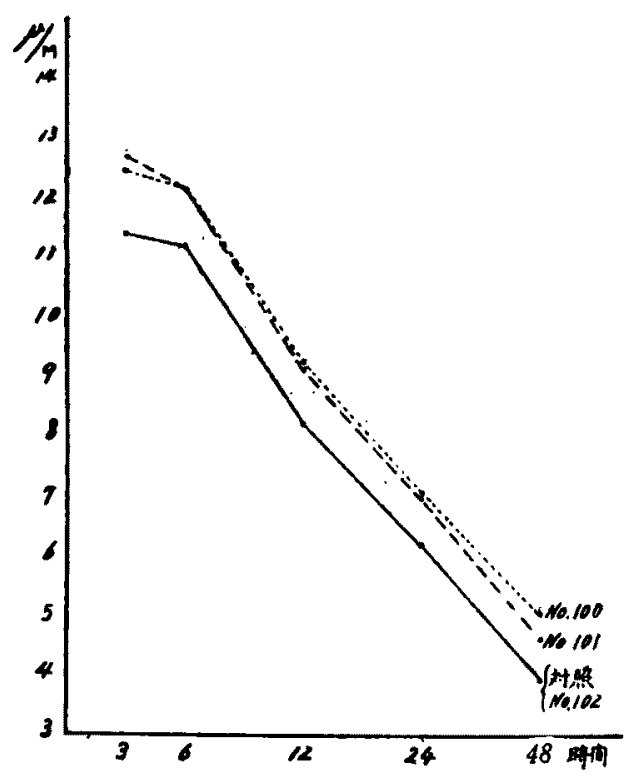

なからた。

2） 3 分間10日連続照射の場合

3 分間10日連続照射例では第30表，第20図 K示与如く 3 例中 1 例は対照と殆んど同值で あるが他の 2 例では有意の差を以つて遊走速 度の充進をみた。

3） 3 分間20日連続照射の場合

3 分間20日連続照射例では，第31表，第21 図飞示す如く 3 例中 1 例は対照 と殆んど同値 であるが，他の 2 例では著明な遊走速度の䒕 進を見た。

第31表 3 分間20日連綂照射の遊走速度 (偽好酸球) $\mathrm{r} / \mathrm{min}$.

\begin{tabular}{|c|c|c|c|c|c|}
\hline 家鬼番号 時間 & 3 & 6 & 12 & 24 & 48 \\
\hline No. 104 & 11.42 & 12.22 & 9.62 & 9.94 & 5.22 \\
\hline No. 105 & 13.41 & 12.24 & 9.24 & 7.12 & 5.60 \\
\hline No. 106 & 11.42 & 11.12 & 8.21 & 6.03 & 3.88 \\
\hline No. 107(対照) & 11.36 & 11.21 & 8.21 & 6.12 & 3.92 \\
\hline
\end{tabular}

第21図 3 分間20日連続照射の遊走速度 （偽好酸球） $\mu / \mathrm{min}$

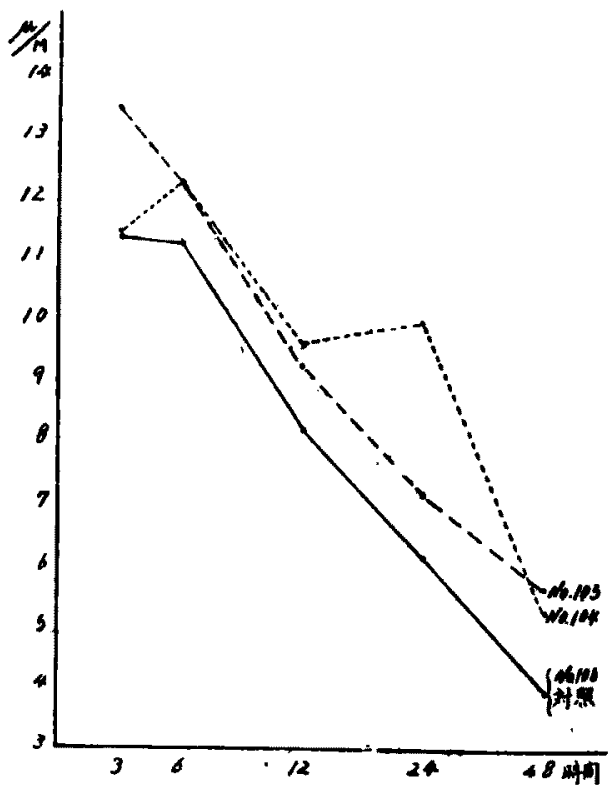

4） 30 分間照射の場合 30 分間照射直後 24 時間後，48時間後に於け 万遊走速度は第32表，第33表第34表に示す如 く有意の差を認めなかつた。 
第32表 30 分間照射直後の遊走速度 (偽好酸球) $\mu / \mathrm{min}$.

\begin{tabular}{l|c|c|c|c|c}
\hline \hline 家鬼番号 & 3 & 6 & 12 & 24 & 48 \\
\hline No. 108 & 12.51 & 12.03 & 8.21 & 6.05 & 3.96 \\
No. 109 & 12.60 & 11.75 & 7.85 & 5.78 & 4.01 \\
No.110 & 12.34 & 12.19 & 8.47 & 6.11 & 4.15 \\
No. 111(対照) & 12.10 & 12.62 & 8.62 & 6.32 & 3.42
\end{tabular}

第33表 80 分間照射24㭙間後の遊走速度 （俏好酸球） $k / \mathrm{min}$.

\begin{tabular}{|c|c|c|c|c|c|}
\hline 家鬼番号 ${ }^{2}$ & 3 & 6 & 12 & 24 & 48 \\
\hline No. 112 & 11.98 & 12.64 & 8.11 & 6.14 & 3.20 \\
\hline No. 113 & 12.64 & 12.54 & 8.29 & 6.12 & 3.29 \\
\hline No. 114 & 12.39 & 12.67 & 8.83 & 6.51 & 3.59 \\
\hline No. 115(対照) & 12.10 & 12.62 & 8.62 & 6.32 & 3.42 \\
\hline
\end{tabular}

第34表 30 分間照射48時間後の遊走速度 (偽好酸球) $\mu / \mathrm{min}$.

\begin{tabular}{l|c|c|c|c|c}
\hline \hline 家鬼番号 時間 & 3 & 6 & 12 & 24 & 48 \\
\hline No. 116 & 11.42 & 11.01 & 7.98 & 5.53 & 3.43 \\
No. 117 & 11.40 & 10.98 & 7.95 & 5.81 & 3.39 \\
No. 118 & 12.71 & 12.60 & 8.29 & 6.07 & 5.40 \\
No. 119(対照) & 12.10 & 12.62 & 8.62 & 6.32 & 3.42
\end{tabular}

\section{第 4 袁 実験成精の総括}

以上の成縝を総括すると次の如くである。

1） 3 分間照射を行了と骨髄内血球の放出 Kより栄美静脈血中の赤血球, 網赤血球, 白 血球（特飞偽好酸球）の增加を来し，これ等 の増加は照射後 30 分より始り，1 万至 2 時間 後に最高に達し 4 乃至 6 時間後に旧に復し, 股動脈血の增加は軽度である。照射 1 洔間後 の骨髄内血流は促進を示したが同じく1時間 後の骨䯣組織像には著変を認めない，次に骨

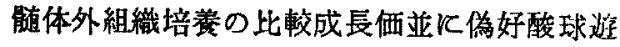
走速度は照射直後，2 洔間後には変化なく24 時間後に元進を示し，48時間，72時間後には 変化を認めない.

2） 3 分間20日間連続照射を行 万と耳静脈 血の軽度な血球增加を見，骨髄組織像飞る軽 度の機能元進像を認め，骨䯣体外組織培盖の 比坹成長価並飞偽好酸球避走速度は有意の元
進を示し，尚これは10日間連続照射例飞も認 められた，20日目の照射後に於ける骨䯣栄養 静脈血の変化は 3 分間 1 回照射例と同棣に骨 髄内血球の放出，骨䯣内血流の促進を認め t.

3） 30 分間照射を行 5 と血球の骨髄内㧕留 により栄童静脈血中の赤血球, 網赤血球, 白 血球の減少を来し，これらの減少は照射直後 乃至 1 時間後が最高で 3 乃至 4 封間後に旧に 復し股䣦脈血の增加は軽度である。次に照射 直後の骨餚内血流は著明飞遅延を示したが同 しく照射直後の骨髄組織像には充血像の他著 変を認めない，骨膸体外組織培養の比較成長 価並に偽好酸球遊走速度は直後，24時間後， 48封間後凡て変化を認めない.

4）鉤虫症患者血清灌流によつて薏起され る大腿骨々髄スペレは 3 分間照射で解除され る. 即ち血球减少も軽度であり，その恢復る 短縮され又遅延すべき血流す正常化認められ る.

\section{第 5 章考按}

Schliephake ${ }^{87)}$ が波長 $10 \mathrm{~m}$ 以下の高周波蓄 電器電界を利用する超短波療法を創め広く医 療供し，その生物学的作用に関する研究。 Schereschewsky ${ }^{88)}$ 䈪矢とし，Schliephake ${ }^{87)}$ が系統的に研究して以来内外の学者により種 ↔の角度から究明されて来た。桶口20)によれ ば超短波の生物学的作用の一は組織の加温で あり, 誘電体として畜電器電焽に㨂入された 組織柱誘電損により温度が上昇する事，其の 他超短波の選択作用，発生機による温熱の発 生と其の特殊分布並びに特殊電気的作用，化 学作用等がありこれらの総和が一括生体に働 き，生体はそれに反灾し，茲に超短波の生物 学的作用が著起されると述へている。

血液部門に於ける超短波の生物学的作用に 関する研究の中で，流血中の各種血球の変動 機忶飞就ては, Christie \& Lomis ${ }^{89)}$, Heller ${ }^{90)}$, 大竹 10 ) 等は単なる温䓡作用によると述べ, Stieböcke ${ }^{91)}$, Groag et al ${ }^{92)}$, 毛利 ${ }^{40)}$, 橋本・ 高橋 ${ }^{38)}$, 平汇 ${ }^{93)}$, 古川・船川 ${ }^{39)}$, 山田 ${ }^{942}$ 等 
促熱作用に加うるに電第的特殊作用を主張し て括り，更に天野・笹田”蛙の摘出心䑏化 対する作用に於て迷走神経の末梢を制戟する と述へ，Pflomm4) は䓪の蹼間血管に及活す 作用江於て超短波通電が交感神経麻㾝的作 用するが，强度通電では副交感神経刺戟作用 もあると述べ，古川・船川 ${ }^{399}$ は家鬼頭部照射 中の白血球の変動を钼察し，自律神経系の一 方的変調《よると云うよりは恐らく両者が相 を異にして変調を来すためであろ 5 と述へ， 高橋14!孫家頭部照射による循環血量, 血液 酸素消費量，心分時血量，心搏出量の变化を 観察し間脳に存在する自律神释中枢の機能変 調によると論じている。

間脳照射に於ては間脳飞存在するとされて いる自律神経の高位中枢が刺载され，各種の 植物性機能飞影響を与え複雑な問題が生してて 来るのは止むを得ない。

体温上异の血液像に及ほす影響飞就て長 島 ${ }^{95)}$ は家兔を温箱に入れ肛門内温度で 43 $52^{\circ} \mathrm{C}$ K 30 分間加温し白血球減少, 偽好酸球 減少を認め，高橋・内藤 ${ }^{93}$ ! は超短波照射飞よ る体温上昇と白血球像との間注何等一定の 関係を認めないと述へ，北山・池上66)，井上・ 前原 ${ }^{67}$ ，橋本(毫) ${ }^{97}$ 等は温刺戟により白血球 增加を認めている。私の寒験では体温の変動 は軽微であり，3 分間照射では $1^{\circ} \mathrm{C}$ 以内，30 分照射でる最高 $2.3^{\circ} \mathrm{C}$ Кすぎないことより これを除外することが出来る。

先人諸家の寒験により間脸に於ける血球調 節中枢の存在部位として視床下部の死白結凘 が確筷視されて居り，往つて私の実䮖に於て もこの部の刺戟が重視されなければならない。 間暚を穿刺又は刺戟し，末梢血液像の変化を 検したるのは，緒言に於て述へた如く枚桨に いとまの無い程であるが，超短波頭部照的に より末梢血を娭したものは数氏にすぎず，更

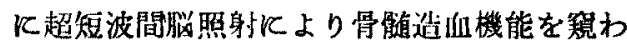
えとしたものは米だこれを見ない，最近西 川・風本 ${ }^{62}$ (黑津氏64)の所谓父感带並飞副交 感带の電気刺戟に依り家震末梢血並飞大腿骨

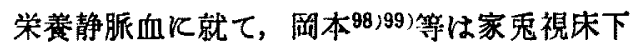

部電気刺戟でリンパ球に重点を括き末梢血並 飞栄養静脈血飞就て，教室塩見 ${ }^{46} は$ は楾間脳 照射を行い程々の角度より，骨㵦造血機能飞 就て興味ある報告を行つている。

Schliephake ${ }^{5)}$ は超短波䫓部通電は白血球 増加を来すが腰部或は四肢通電では照射直後 に減少するのを認め，通電部位に依り白血球 に及ほす影響が異なると述へている，橋本・ 高橋 ${ }^{38}$ は家鬼頭部を約 2 分間照射し, 白血球 数は最高 4 倍偪加し，偽好酸球，好酸球， 好塩基球は共に直後より或は直後一過性に減 少した後増加し， 2 万至 6 時間で最高に達し， 6 乃至 18 時間で照射前値に復する変化を見， 間脳㵔しい機能的又憘質的変化を受ける 結果であると述べている，古川・船川399/家 鬼頭部亚飞上腹部を30分間照射し，照射中の 白血球数を検し，頭部照射の方が上腹部照射 より減少が大であり，10分後飞4796減少，20 分後飞 32 9減少， 30 分後飞 $21 \%$ 減少を示し， リンパ球の減少が好中球の減少に比し大であ ると述へている，毛利40) は頭部照射飞於て次 の如く述べている。即ち 5 分間照射では白血 球数は照射直後より増加し，3 万至 6 時間後 に最高50\%増に達し 1 乃至 2 日後に旧に復し， 好中球の増減は白血球の変化に平行し，その 百分率及び寒数值（125 96增）共飞著明飞増 加し，平均核数は稍々減少し左方移動を示し， リンパ球は偽好酸球と反対に減少し，単核球 が增加の傾向を示す。.15分間照射では大体3 分間照射と同様であるが白血球增加の程度が 稍々低い，30分間照射では直後乃至 3 時間後 飞軽度飞減少（11\%＼cjkstart減）し，偽好酸球の百分 率は大となるが累数值には変化なく，リンパ 球の減少（2596減）が主因をなし，次いで6 归間後に軽度に增加（25\%增）するがこれは 偽好酸球の增加（121\%增）が主困をなすと 正べている，教室塭胃 ${ }^{46)}$ は家鬼間脳レ線照射

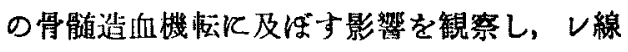
間脳弱照射により骨粗内血流の促進を来し， 為飞血球の骨䯣外放出が起り，抑制星照射飞 より骨䯚内血流の遮延を米し，為に血球の骨

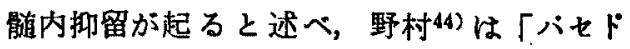


ウ」氏病患者に，150r間脳々下垂体系照射 を行い照射後一時白血球の減少を生じやがて 照射前値飞復し，更に增加の傾向にあると述

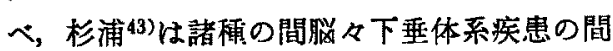
脳照射を行い $1 / 4 \mathrm{H} \cdot \mathrm{E} \cdot \mathrm{D} .5$ 乃至 10 分間照 射で赤血球增多並飞著明な䊝状赤血球の増加 を認め，特飞幼弱型の增加を示すと述へ，中 村(三) $)^{45)}$ は家鬼間脳照射を行い弱照射で赤血 球，網赤血球の增加を，大照照射で赤血球の 減少を見, 網赤血球は增加するも幼弱型の出 見を見ないと述へ，江川47〕は大で 80 r間脳 照射を行い赤血球数は生理的範囲を動播し， 白血球数は照射直後僅かに減少或は減少せず そ急激に増加し 8 乃至 24 時間後に旧に復し, 好中球は白血球数の堌減にほほ平行して増減 し、リンパ球はこれと反して增减すると述へ ている。千田・井上411，井上・他 ${ }^{42}$ は家鬼頭 部飞極超短波を用い，15万至 120 分間照射し 赤血球，血色素の著明な減少を見るす網赤血 球には変化なく，白血球数は直後より或は直 後一時诚少して後增加し，核左方推移を伴引 偽好酸球増加，並にリンパ球の減少を見たと

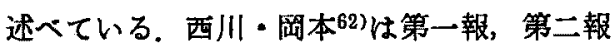
飞於て黑津の所謂交感带亚飞副交感带の電気 刺戟契験を行い交感带刺戟により末梢血，並 飞骨䯣栄養静脈血の偽好酸球の核左方推移を 伴 5 白血球增加，網赤血球の增加を見，交感神 経の刺戟状態と栄養静脈血との密接な関係を 認めながらる，末梢血と栄落静脈血とに於け る変化が大体同様で，むしろ白血球増加は末 梢血の方が大なることより交感神経剌戟によ る白血球増加は骨髄以外の装素が加わると述 ベている，更に副交感刺戟では特記すべき変 化を認めず，副交感神経の興蒘は骨䯣よりの 血球出動の像を見ないと云う。阙本・小田98), 山中・阙本 ${ }^{99}$ は交感带刺戟直後飞リンパ球增 多を認め,この機㯹に就てはリンパ組織から 末梢リンパ管，胸管を経て静脈角火入る正常 経路, 或は何れかの器管, 例えば脚缄等から 循環血内に流れるのではなく随所のリンパ組 織から，そこへ来ている細動脈内に放出され る為と考光，リンパ系に於ては交感神経系の
一眭的な剌戟はリンパ節より血球出動的に作 用し，副交感神経は出動飞は何等作用を及添 さないが，リンパ球産生促進に作用すると述 ベている。私の 3 分間照射並飞 30 分間照射 による成績は，末梢血の白血球飞就ては，橋 本・高橋38)，古川・船川(39)，毛利40)，江川47) の成樍に，赤血球亚飞網赤血球仗就ては，野 村44)，杉浦(3)，中村45)の成樍に一致し栄羡静 脈血並に同時飞検した股動脈血飞於ける赤血 球，絧赤血球，白血球数の変化はレ線間脳照 射に於ける塩見46)の成績と略々同様である。 3 分間照射即ち弱照射を連続して行つた例で は，塩見 ${ }^{46)} の$ 成績並飞超短波頭部照射の上 坂 ${ }^{12)}$ の成績と反し馴れの現象を見ず，極超 短波照射による白血球增加に於ける南(00)の 成積と一致する．嗵口(19)は 2 年以上超短波療 法を行つた患者の血液像に蓄積作用を思わせ るすのが無かつたと述へている．然しこれ等 の成績はいずれる末梢血液像より見たすのと すぎず，私は栄養静脈血像の变化より見たる ので一層意義が深いと考える。

扨，血球数の变化は末梢血は勿論，栄養静 脈血も共に種々なる血液貯臟器官の介在飞よ る血球分布状態の変化, 血管運動神経の作用, 造血蔵器の機能状態，血球破箦の強度，ホル モン，毒素等の影響を受けるものである、故 に骨髄機能を窥 5 場合には末梢血と栄養静脈 血との間の解離に注目しなければならない。 私の寒験に於ける血球の增隇には，末梢血と 見なされる股動脈血と，栄羡静脈血との間に 有意の美を認め，同時期に測定した骨髄内血 流の促進並飞遐延飞より，骨骮直内血球の放出 或は㧊留を生ずることが藾われる。或種の血 球即ち網赤血球では，赤血球に於ける如き解 踓が見られず骨䯣以外の脿器む，その増減に 関係することが考えられる。即ち安井101)は 朝滕は老朽な赤血球並泊白血球，未熟な赤血 球並に白血球を捕拝処置し，常に正常成熟度 の細胞を一般循環血液中下保つ作用があると 云い，その灌流実験で幼弱血球の遊出を見， 自律神経毒で灌流を行い，網赤血球が末梢血 の 3 乃至 5 倍に增加したと述へ，末長 ${ }^{102)}$ は 
腎臟灌流を行い，網赤血球等の未熟血球の増 加を見，骨䯣より放出される未㛙血球は腎臓 飞於ても㧕留されると述べ，火杉103) は肝䑏， 兵頭104) は肺淢に於てそれぞれ灌流を行い， 主に白血球，その中です殊にリンパ球の抑留 を行う等と述へていることからるらなづける 所である，白血球種類に就ては偽好酸球が增 加，リンパ球の減少或は比較的娍少を生ずる ことは諸家の一致する所であり，私の成縝で も同漛であつた，次にリンパ球の減少に就て は岡本・小田 ${ }^{98}$ は副交感带刺戟では胸管内の リンパ量並に細胞密度が減少し胸管から血液 中に移行する細胞が減少すると述べて居り， 前記の肝臟，肺蔵に於けるリンパ球㧕留る その一因をなすと考えられる。 Eppinger \& Hess ${ }^{106)}$, Bertilli et al. ${ }^{106)}$, Hoff ${ }^{107}$ )等(自律 神経系に上る調節に就て，交感神経か興檑す れば核左方推移を伴う好中球増加が起り，迷 走神䅅乃至副交感神経が興窗すれば，リンパ 球並飞好酸球増加が起り好中球が減少すると 云うが，江川47は照射前の白血球百分率で好 中球が多くリンパ球が少いすの, 即ち $\frac{\mathrm{N}}{\mathrm{L}}$ の值 の大なるすのは照射後 $\frac{\mathrm{N}}{\mathrm{L}}$ の值が減少し，照射 前之と反対のすのは $\frac{\mathrm{N}}{\mathrm{L}}$ の值が増加し，前者で は白血球の減少，後者では增加を示し，これ は要するに照射前交感神释緊張型を示すのの は照射後副交感神経緊張型へ，照射前副交感 神経緊張型を示すものは照射後交感神释緊張 型へと転換すると述べている，橋本＝高橋38 は好中球，リンパ球共に增加を認めると述へ， 諸氏の意見の一致しないのは照射条件，被照 射体の植物機能状態，並にその感受性の茥異 とよるものであろう。

教室内藤 ${ }^{108)}$ ，藤(田 ${ }^{84)}$, 副島 ${ }^{85)}$ の他に宮

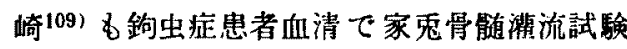
を行い，栄羡静脈血像並と骨随像よりKnochenmarkssperre が惹起されると述へ，副 島 ${ }^{84)}$ は更にこの機枟を骨䯣動脈系の收縮によ

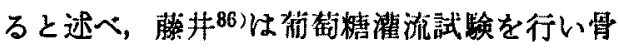
隺内血流の羊延を認めて居る。私の実験では， 鉤虫症患者血清淮流飞より惹起される Kno- chenmarkssperreが著明に軽減されると共に， 早期に解除されるのを知り，間脳レ線照射に 於ける塩見 46 の成績と一致した。

运藤9) は種々の動物に於て死飞到るまで超 短波全身照射を行い, 剖検飞より肺臟, 肝喏 等の荿器に充血像を認めているが，私の脳間 照射例飞於ては，3 分間照射では著変を認め ないが，30分間照射㨁後の骨䯕組織所見で著 明な充血像を認めた。これは Cignoli')の云 万如く超短波最強度通電では，血管が強度に 搪張して血流が静止するに至るといつている がこれに近い状態㯰かれた為と考える。 3 分間連続照射例の骨髄実質細胞並飞骨䯣巨 核球の增加は，次に述べる骨髄体外組穖培養 の結果と共に骨檤機能の立進を物語るすので ある.

山田 ${ }^{94}$ 《超短波の家鬼腹部照射を行い，短 時間照射では白血球遊走速度が元進し長時間 照射では堿退すると述へ，井上110)は超短波 電界内に於汁る白血球の遊走速度, 並飞生存 期間を観察し，500 MA 電界内で既に障碍を 認め，MA の增加と共飞障碍の度が大となる と述へ, 志田・武田111) 83000 MA, $2000 \mathrm{MA}$ 照射の電界内に家兔を20分，10分間括入しそ の白血球活力の一時的減退を認めている，私 は骨邻道体外組織培羡法《より骨䯣の機能を動 態的に観察し, 被墇培養の成績に於て, 間畄 3 分間照射直後亚に 2 時間後には著变なく, 24時間後に增生及び偽好酸球遊走速度の亢進 を見，48 時間， 72 時間後は著変を認めない. 永瀬 ${ }^{73)}$ の交感神経切除家鬼骨艏に於ける術後 5 日目飞侓側に比し增生面積及び遊走速度が 大であると云う成績飞比し，骨㵦機能の亢進 の時期が早いのは，末梢性自律神経作用と中 枢性自律神経作用との相造によるすのと考え る. 3 分間連綂照射例飞於て期待した程度の 光進が認められなかつたのは，正常動物飞加 えられる血管作用に基く增血刺戟は等制限に 有效でない為であるう。

自律神経と骨髄飞就ては, 教宝の藤田 ${ }^{84)}$, 副島 $\left.{ }^{85}\right)$ 等は各種自律神経毒の骨髄淇流試験を 行い, 又同時に行つた骨䚓内血液循㻴状態の 
測定により，骨檤動脈系の拉登は骨䯣内血流 を促進し，骨㵦内飞满留している血球の放出 を，動脈系の收縮は，その反対に骨骾の血球 抑留を起すことを明らかにし，緒方 ${ }^{112) 113) ~ む ~}$ 交感神释毒は骨髄内血流を抑制乙副交感神経 毒はこれを促進すると述へ，教室塩見46) 間 脳し線照射に於て自律神経の作用を重視して いる. 前とる少し嗵べたが, Cignoli1"は超短 波通電の強弱が自律神経系に及ぼす影響を観 察し, 微量通電は血管拡張神経を刺载し, 中 等量通電で收縮神経を刺戟し，最強度通電 では血管が搪張して血流が静止するに至ると 述へ，黒津 ${ }^{64)}$ は自律中枢に於ては，交感神経 系の方が感受性が強いのでさきに刺戟される と述へている，間脳超短波照射に於ても，自 律中枢殊飞副交感神経系を適度飞刺戟し，或 は強度に刺载し得るわけであり，これ等の興

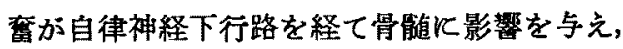
血球の放出或は抑留を生ずることる考えられ るが，間脳照射奏験住艾感带或は副交感带等 の局所刺载ではないので介入する要素が多く， いずれの神経系の変化に属するかを決めるに は慎重でなければならない。教室柴田72) 永 瀬 = 石田 $\left.{ }^{73}\right)$ 《腰部交感神経切除並飞副交感神 経切除を行い，その骨䯠に及ぼす影響は所謂 血管作用が主体であり，その結果実質にる二 次的影響を与立，前者は骨骮通の血球生成を促 進し，後者はこれを抑制すると述へ，教室田 中 ${ }^{76)}$ (骨咀内神経分布は動脈系, 殊飞中等径 の動脈に最す多く，静脈系並飞実質内の神経 分布量は動脈系に比し極めて少く，これより 骨髄内血球の抑留並飞動員機転は，動脈系が 大以に関与するるので静脈系は受動的立場に すぎず，実質に括ける血球生成には重大なる 意義を有するすのとは考えられないと述へて

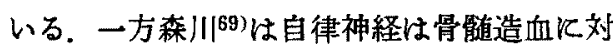
して直接影響を及ほし，副交感神経は促進的 K，交感神経は㸡制的に作用すると述へ，竹 $山^{75}$ 怯骨髄内神経分布飞於て血管運動性飞関 与するるのと，血球形成に関与する二種の神 䅅の存在を主張している．所で私の骞験成績
が果して自律神経の関与によるるのであると しても，骨鹃体外組織培養の成績，即ち骨艏 内血球の放出並に抑留される時期に於ける培 養成績に変化を見なかつたことより，自律神 経が骨璡実質に於ける血球生成に直接一次的 K関与していないと考えられる。

执，私は柴田 ${ }^{22}$ ，永瀨・石田 ${ }^{73}$ ，田中 ${ }^{76)}$ 等" の説に替离を表したいが骨䯣機能を含めた血 球の中枢調節に関しては，これ等の神経一血 管性調節説，神経一集質性調節説の他飞，神 経-体液性調節説並江内分泌性調節説等があ り，俄かに断定出来ない問題である。

\section{第6 章 結論}

私は家鬼の超短波間脳照射を種々の条件で 行い, 大腿骨栄養静脈血像の観察並飞骨䪔内 血液循環状態の測定を行い，併せて骨䯣組織 所見亚飞骨䯣体外組織培養を行い次の結墖を 得た。

1） 3 分間照射を行 5 と骨䯣内血流が促進 され，為に骨髅内血球の放出が起るが，この 時期の骨髄実質に於ける造血機能飞は変化を 見ない，然るに照射後24時間後に於ては骨䯣 内血流の促進に基く実質に於ける著明な造血 機能の 2 次的の元進を認める.

2） 3 分間連続照射を行 5 と血球增加並に, 骨髄造血機能の六進は軽度であるが照射後の 骨髄内血流の促進並飞骨䯣内血球の放出促進 の機転には慣れの状態を見ない.

3） 30 分間照射を行 5 と骨骾内血流の荤延 が起り，為飞骨髄内に血球抑留が起り，その 時期に於ける骨髄には血球抑留の像を見るる 骨䯣実質の造血機能飞は変化を見ない.

4）鈎虫症患者血清灌流後飞 3 分間照射を 行らと鈎虫毒素によつて惹起される Knochenmarkssperre は柽度でありその解除も早い.

擱筆するに当り御愁鹪なる御指導と御校閲を賜つ た恩師平木政授に深萝の謝意を表すると其飞絶えず 御援助を睗つた大藤助数授炕深愔する。

(文 献 後 揭) 


\title{
Hematopoietic Functions of the Bone Marrow in the Cases Irradiated with Ultra-short Waves on the Diencephalon
}

Part 1

\author{
Blood Cell Mobilization and Depot in the Bone Marrow \\ Induced by the Irradiation of Ultra-short \\ Waves on the Diencephalon
}

By

\author{
Akira Fujimori \\ Department of Internal Medicine Okayama University Medical School \\ (Director: Prof. Kiyoshi Hiraki)
}

By irradiatied rabbits with ultra-short waves on the diencephalon under various conditions, observations on the blood picture in the femur nutrient vein were carried out and the condition of the blood circulation in the bone marrow were measured. At the same time obtaining histological findings and performing the tissue culture of the bone marrow, the following results were obtained.

1) Following the 3 minutes' irradiation, the blood cells in the bone marrow were mobili zed by the acceleration of blood flow in the bone marrow, and scarecely no change of the hematopoietic functions could be observed. After 24 hours, however, the function rose remarkably as the secondary phenomenon of the acceleration of blood flow.

2) Though in the cases wtih successive irradiations every 3 minutes, the increase of both blood cells in peripheral blood and hematopoietic functions of the bone marrow increased but not to the degree mentioned previously. The intensity of acceleration of blood flow and the mobilization of blood cells in the bone marrow in every irradiation were left in about the same degree as in the previous cases.

3) By 30 minutes' irradiation, the bone marrow blood flow was slackened and the blood cells were stored in the bone marrow revealing histologically the depot of blood cells, but the hematopoietic functions remained unaffected.

4) The effect of hookworm toxin generally appearing was reduced to a slight and only transient depot of blood cells in the bone marrow after three minutes' irradiation in the case receiving the human serum with hookworm anemia into the bone marrow circulation. 